\title{
Rpp1 Encodes a ULP1-NBS-LRR Protein That Controls Immunity to Phakopsora pachyrhizi in Soybean
}

\author{
Kerry F. Pedley, ${ }^{1,+}$ Ajay K. Pandey, ${ }^{1,3}$ Amy Ruck, ${ }^{1}$ Lori M. Lincoln, ${ }^{2}$ Steven A. Whitham, ${ }^{3}$ and \\ Michelle A. Graham ${ }^{2,+}$ \\ ${ }^{1}$ United States Department of Agriculture-Agricultural Research Service (USDA-ARS), Foreign Disease-Weed Science \\ Research Unit, Ft. Detrick, MD 21702, U.S.A.; ' ${ }^{2}$ USDA-ARS, Corn Insects and Crop Genetics Research Unit, Ames, IA 50011, \\ U.S.A.; and ${ }^{3}$ lowa State University, Department of Plant Pathology and Microbiology, Ames, IA 50011, U.S.A.
}

Accepted 4 October 2018.

\begin{abstract}
Phakopsora pachyrhizi is the causal agent of Asian soybean rust. Susceptible soybean plants infected by virulent isolates of $P$. pachyrhizi are characterized by tan-colored lesions and erumpent uredinia on the leaf surface. Germplasm screening and genetic analyses have led to the identification of seven loci, $R p p 1$ to $R p p 7$, that provide varying degrees of resistance to P.pachyrhizi (Rpp). Two genes, Rpp1 and Rpp1b, map to the same region on soybean chromosome 18. Rppl is unique among the $R p p$ genes in that it confers an immune response (IR) to avirulent $P$. pachyrhizi isolates. The IR is characterized by a lack of visible symptoms, whereas resistance provided by $R p p 1 b$ to $R p p 7$ results in red-brown foliar lesions. Rpp1 maps to a region spanning approximately $150 \mathrm{~kb}$ on chromosome 18 between markers Sct_187 and Sat_064 in L85-2378 (Rpp1), an isoline developed from Williams 82 and PI 200492 (Rpp1). To identify Rpp1, we constructed a bacterial artificial chromosome library from soybean accession PI 200492. Sequencing of the Rpp1 locus identified three homologous nucleotide binding site-leucine rich repeat (NBS-LRR) candidate resistance genes between Sct_187 and Sat_064. Each candidate gene is also predicted to encode an N-terminal ubiquitin-like protease 1 (ULP1) domain. Cosilencing of the Rppl candidates abrogated the immune response in the Rpp1 resistant soybean accession PI 200492, indicating that Rpp1 is a ULP1-NBS-LRR protein and plays a key role in the IR.
\end{abstract}

The USDA is an equal opportunity provider and employer. Mention of trade names or commercial products in this publication is solely for the purpose of providing specific information and does not imply recommendation or endorsement by the U.S. Department of Agriculture.

Current address for A. K. Pandey: National Agri-Food Biotechnology Institute, Sector 81, Mohali, India 140306

${ }^{\dagger}$ Corresponding authors: K. F. Pedley; E-mail: Kerry.Pedley@ars.usda.gov and M. A. Graham; E-mail: Michelle.Graham@ars.usda.gov

Funding: This research was financed by United States Department of Agriculture Agricultural Research Service Projects 8044-22000-046-00D and 5030-21220-005-00D, the Iowa Soybean Association, the North Central Soybean Research Program, the United Soybean Board, and the National Science Foundation (award number 0820642).

*The $\boldsymbol{e}$-Xtra logo stands for "electronic extra" and indicates that three supplementary figures and six supplementary tables are published online.

This article is in the public domain and not copyrightable. It may be freely reprinted with customary crediting of the source. The American Phytopathological Society, 2019.
Plants are a potential source of sugars and other nutrients to microbes in the environment. Thus, it is not surprising that many bacteria and fungi have evolved mechanisms to overcome the preformed structural and chemical barriers plants use to protect these resources. As a result, plants have evolved additional systems for detecting would-be pathogens and mounting defenses to thwart infection. Collectively these systems and the underlying mechanisms are referred to as plant immunity.

It is now well-established that plants utilize two distinct but overlapping immune responses (Jones and Dangl 2006). The recognition of microbe- or pathogen-associated molecular patterns (MAMPs or PAMPs) activates MAMP- or PAMP-triggered immunity (MTI or PTI) (Dodds and Rathjen 2010; Jones and Dangl 2006). To counter MTI, pathogens deliver effector proteins into the plant cell that interfere with signaling and other downstream defense responses, resulting in effector-triggered susceptibility. Recognition or detection of microbial effectors by plant resistance $(\mathrm{R})$ proteins elicits effector-triggered immunity (ETI), which often culminates with a rapid, localized form of cell death known as the hypersensitive response (HR) (Boller and Felix 2009; Dodds and Rathjen 2010; Jones and Dangl 2006). The HR functions to limit the ability of the pathogen to spread beyond the point of attack. Due to the dramatic and irreversible nature of the HR, it is essential that plants tightly regulate ETI in the absence of a bona fide infection.

Most plant $\mathrm{R}$ proteins contain nucleotide-binding site leucine-rich repeat (NBS-LRR) domains and are encoded by plant $R$ genes (Martin et al. 2003). Many NBS-LRR proteins can be further divided into three functional classes based on the presence of either Toll/interleukin-1 receptor (TIR), coiled coil (CC), or resistance to powdery mildew8 domains located at the amino terminus (Jones et al. 2016; Shao et al. 2016). NBS-LRR proteins are involved in pathogen detection with the TIR-NBSLRR and CC-NBS-LLR classes operating through distinct yet overlapping signaling pathways (Aarts et al. 1998; Elmore et al. 2011). Although many aspects of $R$ protein function remain to be elucidated, there is evidence for both direct and indirect interactions of NBS-LRR proteins with microbial effectors, which initiate signaling cascades that trigger defense responses (Dodds and Rathjen 2010; Jones and Dangl 2006; Jones et al. 2016).

Soybean rust (SBR) is an aggressive foliar disease of soybean (Glycine max) and other legumes caused by the obligate biotrophic fungus Phakopsora pachyrhizi. Three distinct reaction phenotypes occur on soybean in response to $P$. pachyrhizi infection (Bromfield 1984), and the outcome of the interaction appears to follow the gene-for-gene resistance model (Flor 1946). Susceptible soybean plants infected with virulent isolates of $P$. pachyrhizi develop tan-colored lesions (TAN phenotype) 
with abundant, sporulating uredinia on the leaf surface. Resistant plants are characterized by either a complete lack of visible symptoms, termed the immune response (IR), or by the appearance of reddish-brown lesions (RB reaction) in response to avirulent isolates. The IR effectively prevents reproduction of the pathogen and provides complete resistance (Miles et al. 2003). The RB reaction varies with respect to the ability of the pathogen to form uredinia and sporulate and is considered incomplete resistance (Bonde et al. 2006; Miles et al. 2003).

While the identity of the effectors or other determinants that contribute to the recognition of SBR isolates remain unknown, germplasm screening efforts have identified several sources of resistance to P. pachyrhizi (Rpp) that map to seven loci (Rppl to Rpp7) (Childs et al. 2018; Garcia et al. 2008; Hyten et al. 2007, 2009; Li et al. 2012; Silva et al. 2008). Two genes, Rppl (Hyten et al. 2007) and Rpplb (Chakraborty et al. 2009), map to an overlapping region on chromosome 18. Rpp4 (Silva et al. 2008) and Rpp6 (Li et al. 2012) also map to chromosome 18 but to loci distinct from Rppl. The remaining genes, Rpp2 (Silva et al. 2008), Rpp3 (Hyten et al. 2009), the dominant and recessive alleles of Rpp5 (Garcia et al. 2008), and Rpp7 (Childs et al. 2018) map to chromosomes 16, 6, 3, and 19, respectively. With the exception of Rppl, all of the known $R p p$ genes condition a $\mathrm{RB}$ reaction. Rppl but not $R p p l b$ conditions an IR in response to avirulent isolates of $P$. pachyrhizi.

The soybean Rpp genes have yet to be cloned, but a candidate for Rpp4 was identified in the resistant accession PI 459025B (Rpp4) using a combination of DNA sequencing, gene-expression analysis, and virus-induced gene silencing (VIGS) (Meyer et al. 2009). Sequencing the Rpp4 locus in the susceptible cultivar Williams 82 revealed the presence of three CC-NBS-LRR $R$ genes with similarity to the RGC2 $R$-gene family in lettuce. PI 459025B contains alleles of these genes not present in susceptible plants, and one allele (Rpp4C4) was predominantly expressed in resistant plants before and after challenge with an avirulent $P$. pachyrhizi isolate. Gene silencing resulted in the loss of resistance in PI $459025 \mathrm{~B}$, indicating that $R p p 4$ is a CC-NBS-LRR $R$ gene within this gene cluster. To understand downstream genes contributing to Rpp4-mediated resistance, Morales et al. (2013) used microarray analyses to compare gene expression in Rpp4-silenced and control plants two weeks after infection.

In this study, we employed a similar approach to identify the source of resistance at the Rppl locus involved in the IR. We screened a bacterial artificial chromosome (BAC) library developed from the Rppl resistant accession PI 200492 with a variety of markers targeting the Rppl locus mapped by Hyten et al. (2007). Sequencing of the BACs revealed the presence of three novel $R$-gene candidates between markers Sct_187 and Sat_064, which define the Rppl locus. Cosilencing of the candidate genes using VIGS confirmed a role in resistance to P. pachyrhizi. RNA-seq of VIGS plants identified genes involved in the Rppl-mediated defense network. This work shows that Rpp1 is an NBS-LRR protein with a novel ubiquitinlike-specific protease 1 (ULP1) domain.

\section{RESULTS}

\section{Identification of candidate $R p p 1$ genes.}

To identify candidate Rppl genes, a BAC library was constructed using DNA isolated from the resistant genotype (PI 200492). Markers defining the Rpp1 locus (Sct_187 and Sat_064) (Hyten et al. 2007) were used to identify the corresponding region in the Williams 82 genome sequence (Gm18:56,182,230 to $56,333,803)$. Primers for BAC library screening were developed from genes Glyma.18g280900 and Glyma.18g282700, which have relatively few homologs within the soybean genome (Supplementary Table S1). BAC library screening with these primers identified BACs PI_200492_2G03 and PI_200492_2E10 (Fig. 1). Screening with BAC-end primers developed from PI_200492 2G03 and PI_200492_2E10 identified BACs PI_200492_1C06 and PI_200492_1A02. Paired-end sequencing of 691, 402, 935, and 754 subclones from BACs PI_200492_1C06, PI_200492_2G03, PI_200492_1A02, and PI_200492_2E10, respectively, was used to generate a 324,316-bp contig (GenBank accession MH590229) extending past the Rppl locus in both directions. BACs were assembled individually prior to complete contig assembly. BAC coverage ranged from $6.2 \times$ for PI_200492_1C06 to 10.0X for BAC PI_200492_1A02.

BLASTN comparisons against primary transcripts in the Williams 82 reference genome identified 31 orthologus genes in the PI 200492 Rppl contig (Glyma.18G280200-Glyma. 18G282800, Glyma.18G283100, Glyma.18G283200, Glyma. U008900, GlymaU008800). Of these, eight genes had homology to the NBS-LRR family of disease $R$ genes. The genes are abbreviated as $R l$ to $R 8$, corresponding to Glyma. 18G280300, Glyma.18G280400, Glyma.18G281500, Glyma.18G281600, Glyma.18G281700, Glyma.18G283200, Glyma.U008800, and Glyma.U008900. Correspondence was determined by $R$ gene order relative to the Williams 82 genome sequence. Based on multiple sequence alignments, the presence of conserved domains and the presence or absence of introns, the eight candidate $R$ genes could be divided into two classes (Fig. 2 ). Genes $R 1$ to $R 5$ contained NB-ARC (IPR002182), winged helix-turn-helix (IPR011991), and LRR (IPR032675) domains distinct from those in $R 6, R 7$, and $R 8 . R 1$ and $R 3$ to $R 5$ also contained a novel ULP1 protease domain (IPR003653). $R 2$ lacked the ULP1 protease domain and contained several in-frame stop codons, making it likely a pseudogene. $R I$ and $R 3$ to $R 5$ contained three predicted introns, while $R 2$ contained a single predicted intron. $R 6$ and $R 7$ contained an additional $C C$ domain and lacked introns entirely. $R 8$ encoded a partial NBS domain and is also a likely pseudogene. Three $R$ genes $(R 3, R 4$, and $R 5)$, were located between markers Sct_187 and Sat_064 (Fig. 1), which define the Rppl locus (Hyten et al. 2007).

\section{VIGS of the Rpp1 candidate genes $R 3, R 4$, and $R 5$ compromises immunity.}

To determine if $R 3, R 4$, or $R 5$ played a role in immunity, a VIGS construct was developed to silence their expression. If any of these genes were required for the IR, we expected visible lesions indicative of a compromised defense response to develop on silenced Rppl-resistant plants challenged with an avirulent isolate of $P$. pachyrhizi. Since the genes shared 93 to $96 \%$ nucleotide identity, this prohibited the silencing of each gene individually. Therefore, an identical 234-bp portion of the central NBS shared by all three candidate genes was used to generate a single VIGS construct for silencing. Aside from the viral symptoms associated with Bean pod mottle virus (BPMV), propagation of the virus containing the Rppl insert (BPMV: Rppl) did not result in any morphological abnormalities in susceptible or resistant plants, which were visually indistinguishable from control BPMV:GFP (green fluorescent protein)infected plants. For VIGS experiments, Rppl-silenced and control plants were challenged with $P$. pachyrhizi isolate LA04-1 four weeks following the introduction of BPMV:Rppl by rubinoculation. The Rppl-silenced plants exhibited visible RB lesions with limited uredinia formation 14 days after inoculation with isolate LA04-1 (Fig. 3). By contrast, resistance was not affected in plants containing the BPMV:GFP recombinant virus and no visible symptoms were observed. To confirm silencing, messenger RNA (mRNA) from three independent biological replicates was measured by quantitative reverser transcriptionpolymerase chain reaction (qRT-PCR). The Rppl candidate gene transcript levels were reduced $1.67 \pm 0.19$ fold in BPMV: 
Rppl-infected plants compared with BPMV:GFP-infected plants. To verify that Rppl-mediated immunity was compromised in the silenced plants, the accumulation of $P$. pachyrhizi $\alpha$-tubulin transcript was used as a measurement of fungal growth. qRT-PCR performed with cDNA derived from three independent biological replicates from BPMV:GFP-infected plants did not produce a positive cycle threshold $(\mathrm{Ct})$ value through 40 cycles. In contrast, three independent biological replicates of BPMV:Rppl-infected plants yielded an average $\mathrm{Ct}$ value of $36.05 \pm 0.56$, indicating the Rppl-silencing allowed fungal accumulation to occur.

\section{$R 4$ is the most highly expressed candidate} gene in PI 200492, regardless of infection.

To determine which of the candidate $R$ genes contribute to $P$. pachyrhizi resistance, a region of the NBS containing nucleotide differences that could be used to distinguish each of the genes was PCR-amplified from cDNA and was cloned and sequenced. Primers were designed from flanking regions that were absolutely conserved across all five genes in both PI 200492 and Williams 82, to reduce differences in amplification efficiency (Supplementary Fig. S1). Prior to expression analyses, primers were tested on genomic DNA of PI 200492 and Williams 82 to determine amplification efficiency for each gene (Supplementary Table S2). In PI 200492 plants grown under standard conditions in the absence of the pathogen, 7.5, $0,6.2,65.3$, and $21 \%$ of clones corresponded to $R 1$ to $R 5$, respectively, suggesting $R 4$ is the predominantly expressed gene in PI 200492 and confirming $R 2$ as a pseudogene. In contrast, in susceptible Williams 82 plants $2.6,2.5,2.7,10.5$ and $81.8 \%$ of clones corresponded to $R 1$ to $R 5$, respectively, suggesting $R 5$ is the predominantly expressed gene in Williams 82. To test how PI 200492 responded to $P$. pachyrhizi infection, we repeated the experiment, collecting samples 24 and $72 \mathrm{~h}$ after inoculation or mock-inoculation. Again, $R 4$ was the predominantly expressed gene (50. 7 to $63.7 \%$ of clones), followed by $R 5$ (14.9 to $18.4 \%$ of clones). $R 1$ and $R 4$ were slightly induced by $P$. pachyrhizi inoculation at both timepoints, while $R 3$ was repressed. $R 5$ was slightly repressed by $P$. pachyrhizi inoculation at $24 \mathrm{~h}$ but induced by $72 \mathrm{~h}$.

\section{The Rpp1 ULP1 domain is a functional protease.}

To determine if the ULP1 domain was functional, we used the ULP1 protein domains from $R 1, R 3, R 4, R 5$, Glyma.13G256800, and Glyma.15G058100 for BLASTP comparisons to all proteins in the Arabidopsis genome (The Arabidopsis Information Resource [TAIR] version 10). Using an E-value cutoff of $10 \mathrm{E}-4$, we identified seven predicted proteins (ULP1B, ELS1, ESD4, ASP1, At4G33620, OST1, and OTS2). Sequence alignment of the ULP1 domains encoded by the Rppl candidate genes, the Arabidopsis ULP proteins, and the two ULPs from Saccharomyces cerevisiae confirmed the presence of the catalytic triad residues (His-Asp-Cys; Supplementary Fig. S2) required for protease activity. To test for functionality, the ULP1 domains of $R 3, R 4$, and $R 5$ were used to complement $S$. cerevisiae strains that contained mutations in either of the two yeast small ubiquitin-like modifier (SUMO) protease genes Ulp1 or Ulp2. Ulp1 has several functions in yeast, including the processing of Smt3 (SUMO) precursor peptides and the removal of Smt3 from posttranslational conjugates ( $\mathrm{Li}$ and Hochstrasser 1999). Strains lacking a functional Ulpl allele are not viable, due to their inability to progress through the cell cycle, but ulpl temperaturesensitive alleles ( $t s$ ) have been isolated ( $\mathrm{Li}$ and Hochstrasser 1999). A ulpl-ts allele permits growth at $30^{\circ} \mathrm{C}$ but growth at $37^{\circ} \mathrm{C}$ is restricted. The second $S$. cerevisiae SUMO protease, Ulp2, also functions to remove Smt3 from other proteins but is functionally distinct from Ulp1 (Li and Hochstrasser 2000). Null Ulp2 mutants are viable but exhibit a pleiotropic phenotype that includes temperature-sensitive growth $(\mathrm{Li}$ and Hochstrasser 2000). We expressed the soybean ULP1 domains using a strong galactose-inducible promoter. Additionally, we used a truncated galactose-inducible promoter for weaker expression, in case the expressed soybean gene fragment was

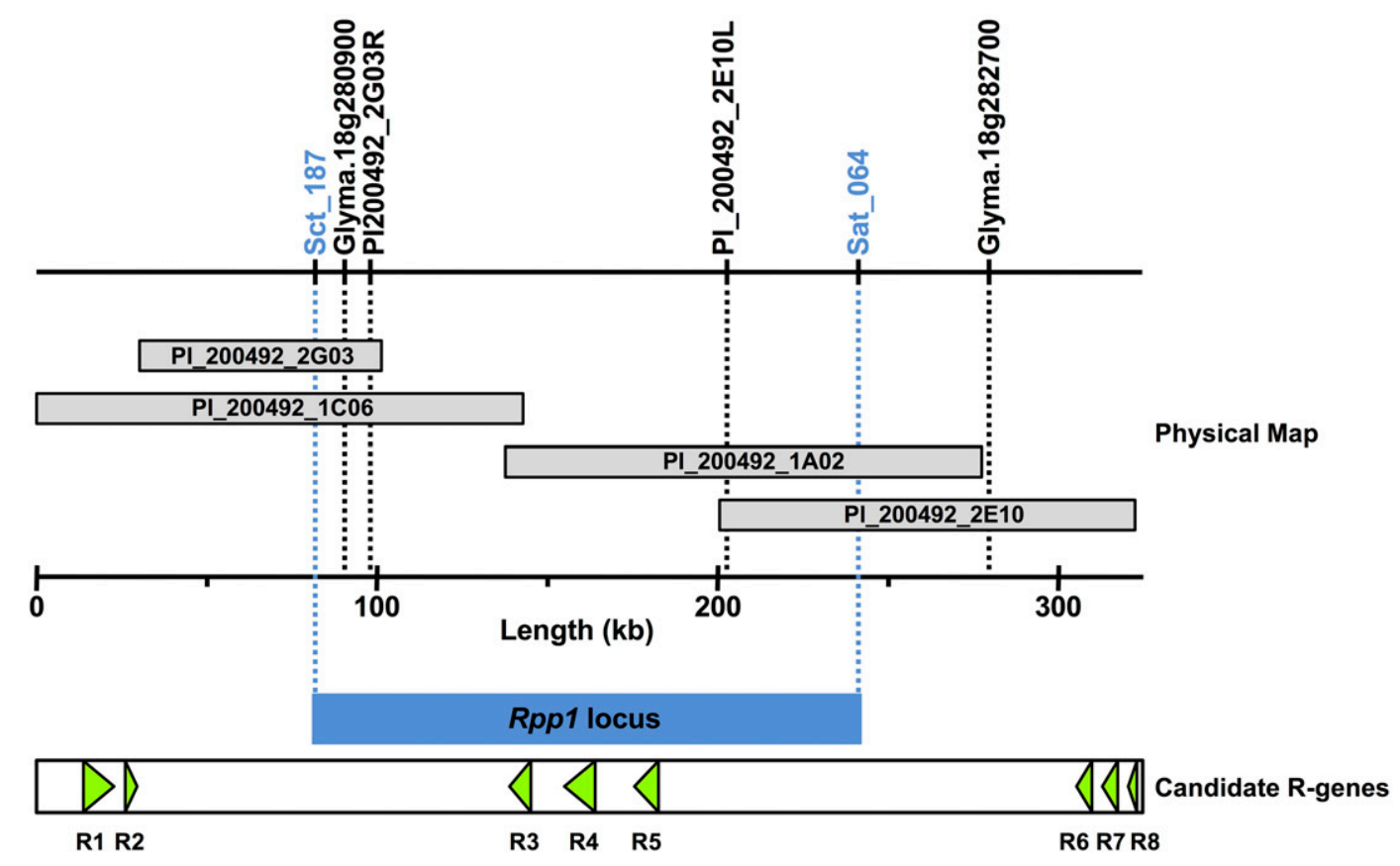

Fig. 1. Schematic diagram of the Rppl locus. Four bacterial artificial chromosomes (BACs) (gray boxes) spanning the Rppl locus on chromosome 18 were identified from a library constructed from soybean accession PI 200492 (Rpp1) DNA. Positions of the physical markers used to map Rpp1 (Hyten et al. 2007), Sct_187 and Sat_046, are illustrated at the top, along with targets of the primers used to screen the library. The blue box indicates the location of the Rpp1 locus. Primers were designed based on the Williams 82 soybean genome sequence or PI_200492 BAC end sequences. The location and orientation of the eight candidate resistance $(R)$ genes is depicted at the bottom (green arrowheads). 
toxic in yeast. Control cells transformed with the empty vectors were unable to grow at $37^{\circ} \mathrm{C}$ on media containing glucose or galactose. The R5 ULP1 domain was able to restore growth in ulpl-ts when expressed at high levels and the R4 ULP1 domain complemented the ulp2 mutant cells at both high and low expression levels (Fig. 4). Conversely, expression of the R4 ULP1 domain encoding a mutation in the catalytic triad (C310S) failed to complement the ulp2 mutant (Supplementary Fig. S3).

\section{Evolution of the Rpp1 locus across legumes.}

To examine the evolution of the Rppl candidate genes across legumes, we took advantage of the Legume Information System Genomic Context Viewer (Dash et al. 2016). Since $R 3, R 4$, and $R 5$ were located within the mapped Rppl locus and were closely related to $R 1$ and $R 2$, we focused our analyses on the region containing $R 1$ through $R 5$ (Gm18 from 56.10 to 56.30 $\mathrm{Mb}$, version Wm82.a2.v1). We identified the homeologous region on soybean $\mathrm{Gm} 8$, representing a genome duplication event and syntenic regions from Phaseolus vulgaris (common bean), Arachis duranensis and Arachis ipaensis (the diploid ancestors of cultivated peanut), Cajanus cajan (pigeonpea), Lupinus angustifolius (narrow-leaved lupine), Lotus japonicus (birdsfoot treefoil), and Medicago truncatula (barrel medic) (Fig. 5). Colinearity was most conserved in legume species most closely related to soybean. We identified two genes, an ethylene-responsive transcription factor and a homeodomain

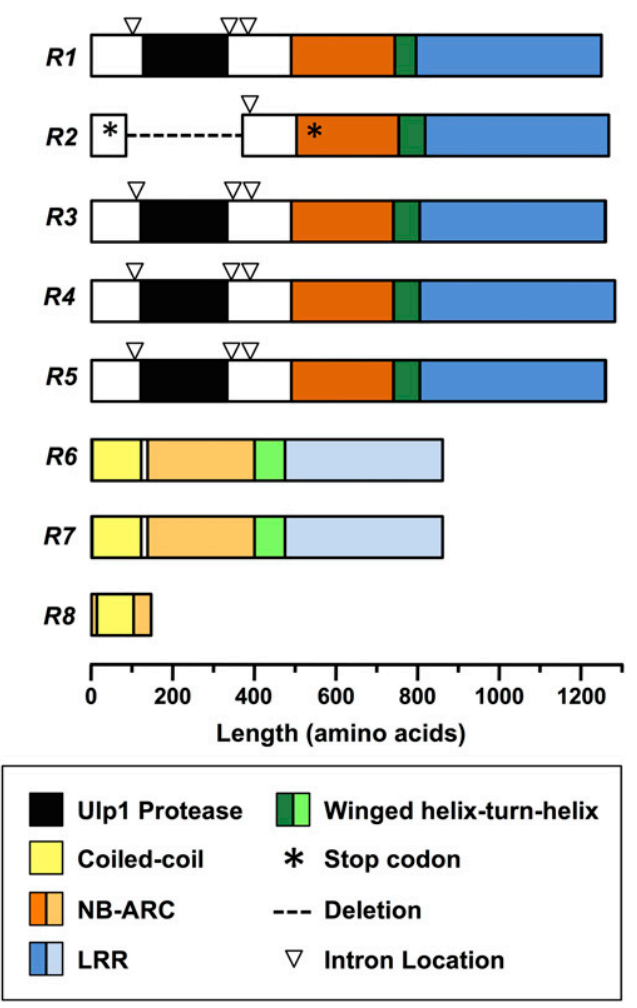

Fig. 2. Structure of candidate resistance $(\mathrm{R})$ proteins in the Rppl locus in PI 200492. Comparisons to predicted genes and transcripts in the Rppl locus from Williams 82 were used to predict $R$ gene structure in the Rppl locus from PI 200492. The programs FGENESH (Solovyev et al. 2006) and the NetPlantGene2 server (Hebsgaard et al. 1996) were used to confirm the positions of exons and splice sites within candidate $R$ genes. InterProScan (Jones et al. 2014) was used to identify conserved domains within R proteins. These analyses divided the $\mathrm{R}$ proteins from the Rppl locus into two distinct classes based on motif differences and the presence or absence of introns in the corresponding genes. Intron lengths (bp) are as follows. $R 1$ : $4,485,328$, and $661 ; R 2: 635 ; R 3 I: 580,329$, and $712 ; R 4: 2,310,332$, and 674; and $R 5: 1,153,330$, and 656 . transcription factor, that flanked the Rppl candidate genes $R 3$, $R 4$, and $R 5$ on Gm18 and were conserved across all eight species and the homeologous region on Gm8. Only Gm18 contained $R$ genes between these flanking genes. InterProScan analyses of all $\mathrm{R}$ proteins from across the entire region in all species confirmed that only the $R$ genes in the Williams 82 Gm18 reference genome contained the novel ULP1 protease domain. Further, BLAST searches failed to identify any additional $\mathrm{R}$ proteins with ULP1 domains from the predicted proteins of any of these species. Taken together, this suggests that the presence of $R$ genes in the Rppl locus and the addition of the ULP1 protease domain is relatively new, following the separation of soybean and its closest sequenced relative, Phaseolus vulgaris. Similarly, Meyer et al. (2009) found that $R$ genes were absent from the region homeologous to the Rpp4 Asian soybean rust-resistant locus. Further, only one additional Rpp 4 homolog could be found elsewhere in the soybean genome.

To understand how the novel ULP1 protease domain was incorporated into the Rppl candidate genes, we used BLASTN to compare the ULP1 domains from $R 1, R 3, R 4$, and $R 5$ to all predicted transcripts in the Williams 82 reference genome. This search identified best reciprocal matches to two homeologous genes Glyma.13G256800 (E < 0.0) and Glyma.15G058100 (E $<10 \mathrm{E}-17$ ), both lacking any $\mathrm{R}$ protein signatures (Fig. 6). While the ULP1 domain in the Rppl candidates corresponded to a single exon, it corresponded to six exons in Glyma. 13G256800 and Glyma.15G058100, which have 16 and 10 exons, respectively. Li et al. (2017) identified 13 ULP homologs in the soybean genome, each containing a minimum of four exons. The lack of introns in the ULP1 domain of the Rppl $R$ genes suggests the ULP1 domain was likely inserted into an ancestral $R$ gene at the $R p p l$ locus by a retrotransposition event, likely within the first intron. Genes flanking a retrotransposon can be duplicated and transposed by readthrough transcription from the retroelement (Hoen et al. 2006). We took advantage of the soybean transposable element database SoyTEdb (Du et al. 2010) to search for transposable elements within all $R$-gene sequences of PI 200492 and Williams 82. We identified a Copia long terminal repeat (LTR) retrotransposon (RLC_Gmr24_Gm10-

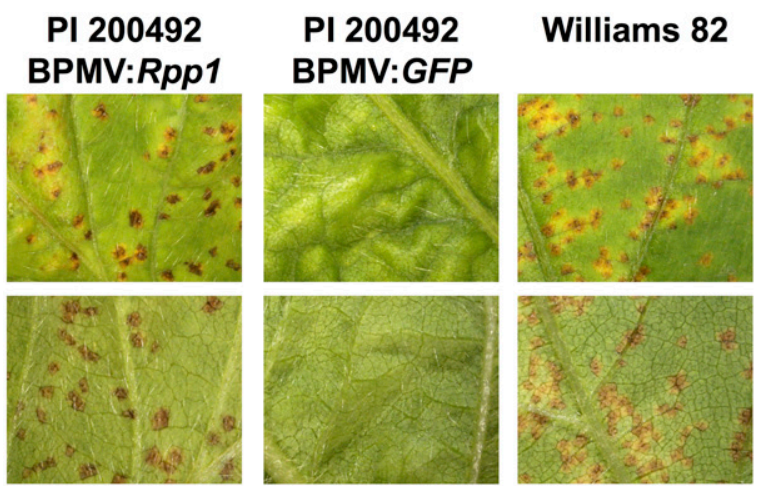

Fig. 3. Loss of Rpp1-mediated resistance in plants following virus-induced gene silencing of Rppl candidate genes. Plants of soybean accession PI 200492 (Rppl) were infected with Bean pod mottle virus (BPMV) carrying either a 234-bp fragment corresponding to an identical region in $R 3, R 4$, and $R 5$ or a portion of the green fluorescent protein gene (GFP) (control). BPMV-infected plants were challenged with Phakopsora pachyrhizi isolate LA04-1 approximately 4 weeks after BPMV inoculation, and symptoms were photographed 2 weeks later. Rppl-silenced plants show typical soybean rust symptoms, indicating a loss of immunity, whereas control plants are immune. Top images show the adaxial leaf surface and bottom images show the abaxial leaf surface. Susceptible Williams 82 soybean plants (not infected with BPMV) were included to serve as a susceptible control. While Rppl-silenced plants have reddish-brown lesions with a few fungal spores, Williams 82 plants have tan lesions with fully sporulating uredinia. 
$\mathrm{Gm} 18, \mathrm{E}=0$ ) in intron 1 of $R 1$ in both cultivars (Fig. 6). The element immediately preceeded the ULP1 domain of $R 1$. Since the element is truncated relative to RLC-GMr24 (2,035 of 2,591 bases) and lacked typical LTRs, it is likely no longer functional.

\section{RNA-seq of Rpp1 silenced plants.}

Previous experiments silencing Rpp4 in PI 459025B resulted in the development of tan lesions with fully sporulating uredenia (Meyer et al. 2009). Microarray analyses of Rpp4-silenced plants revealed that genes normally induced during Rpp4-mediated resistance were repressed by Rpp4 silencing (Morales et al. 2013). In contrast, Rppl silencing resulted in plants with RB lesions and limited uredinia formation. However, inoculation of PI 200492 with compatible $P$. pachyrhizi isolates results in susceptible tan lesions (Miles et al. 2011). This suggests that silencing Rppl compromised immunity to $P$. pachyrhizi but not resistance.

To evaluate the effect of Rppl silencing, the RNA used to confirm silencing was also used for RNA-seq analysis. By comparing gene expression between PI 200492 BPMV:Rpp1infected plants and BMPV:GFP-infected plants, each infected with $P$. pachyrhizi isolate LA04-1, we hoped to identify downstream components of the Rppl signaling pathway responsible for resistance to $P$. pachyrhizi. Sequences for each of the samples are available from the National Center for Biotechnology Informatin Sequence Read Archive as BioProject accession PRJNA479513.

Using a false discovery rate (FDR) $<0.001$, we identified 1,211 genes induced by Rppl silencing and 2,566 genes repressed by Rppl silencing (fold change (FC) $>2$ and $<-2$; Supplementary Tables S3 and S4, respectively). To better understand the biological processes affected by Rppl silencing, we used gene ontology (GO) terms to group differentially expressed genes by function. We identified 32 and $72 \mathrm{GO}$ terms significantly (corrected $P<0.05$ ) overrepresented among genes induced and repressed by Rppl silencing, respectively (Supplementary Table S5). Among the induced genes, we identified significant GO terms associated with defense (defense response, defense response to fungus, regulation of plant HR, respiratory burst involved in defense response, flavonoid biosynthesis, positive regulation of flavonoid biosynthesis, and phenylpropanoid biosynthesis), transport (amino acid, nitrate, proline, adenine, guanine and oligopeptide transport, amino acid import, and phloem sucrose loading), metabolism (chlorophyll, lipoate, vitamin and sulfur amino acid, oxidoreduction coenzyme and secondary metabolism, and regulation of lipid metabolism), and biosynthesis (coenzyme, oxylipin, fat-soluble vitamin, and sulfur compound biosynthesis). GO terms overrepresented among Rppl-silencing repressed genes included those associated with photosynthesis (photosynthesis, light reaction, light harvesting, response to far red and red light, electron transport, and others), growth (growth, cell-tip growth, multidimensional growth, regulation of cell size, and meristem growth), defense response (incompatible interaction), abiotic stress responses (response to cold, dessication, sucrose, and temperature stimulus), and biosynthesis (biosynthesis of chlorophyll, brassinosteroid, lignin, cutin, carbohydrate, and lipids). This suggests that Rppl silencing repressed photosynthetic processes, abiotic stress responses, and growth while inducing defense, similar to resistant responses governed by Rpp2 (van de Mortel et al. 2007), Rpp3 (Schneider et al. 2011), and Rpp4 (Morales et al. 2013).

Morales et al. (2013) identified 54 probes unique to resistance responses governed by Rpp2, Rpp3, and Rpp4. Using the SoyBase Gene Model Correspondence Lookup, these correspond to 42 genes in the current genome assembly. Of these, 11 were also differentially expressed in response to Rppl silencing. Morales et al. (2013) also used microarray analysis to identify genes differentially expressed in response to Rpp4 silencing. Of the 260 genes differentially expressed in response to Rpp4 silencing, 97 were also differentially expressed in response to Rppl silencing. Of these, 89 genes (92\%) were repressed by $R p p 4$ silencing. In contrast, 62 genes $(70 \%)$ were induced by Rppl silencing, again suggesting that Rppl silencing compromised the IR but not defense.

To identify the transcription factors responding to Rppl silencing, we took advantage of the SoyDB Transcription Factor database (Wang et al. 2010). We identified 348 differentially expressed transcription factors, representing 39 transcription factor families (Supplementary Table S6). Of these, WRKY,

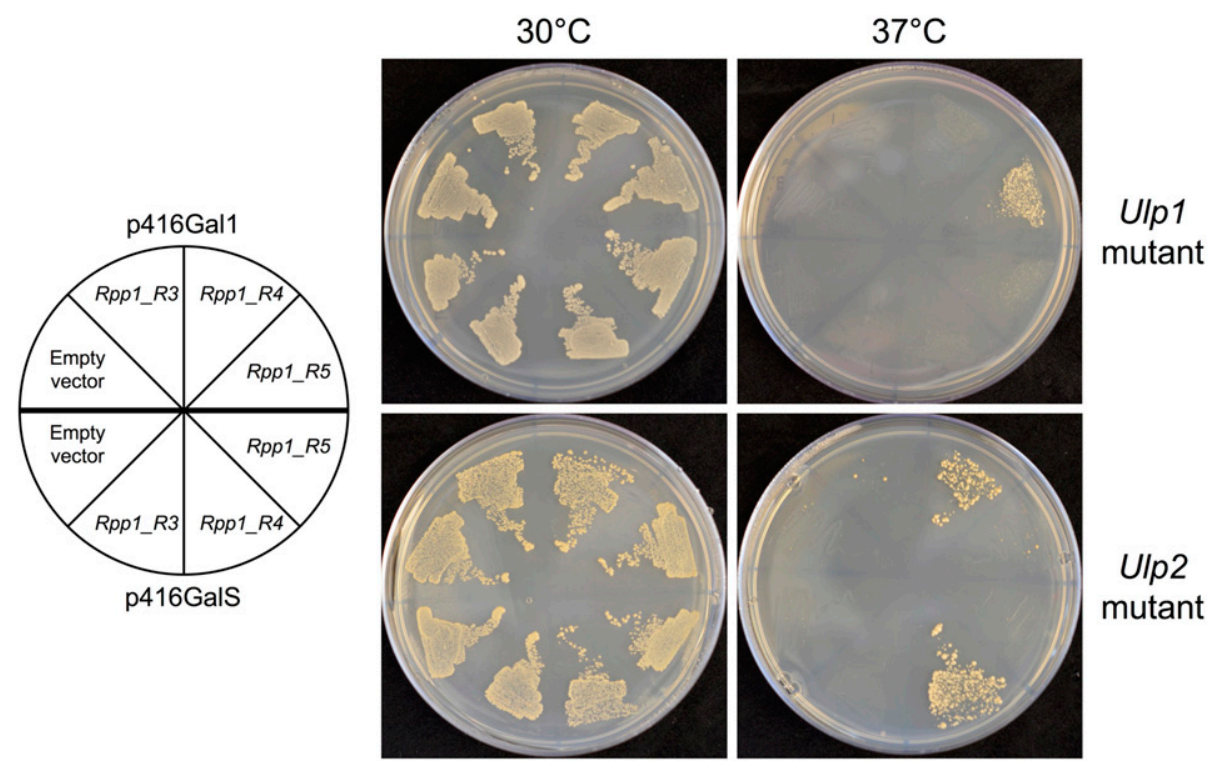

Fig. 4. Complementation of yeast mutants by $R p p 1$ candidate gene ULP1 domains. The ULP1 domains of $R 3, R 4$, or $R 5$ were expressed from either a strong (Gal1) or weak (GalS) promoter in yeast mutants carrying either a temperature-sensitive (ts) allele of $U L P 1$ or lacking the $U L P 2$ gene. Both yeast mutants are normally impaired at $37^{\circ} \mathrm{C}$. The Rpp 1 R5 ULP1 domain was able to partially restore growth in the $u l p 1$ ts mutant cells when expressed at high levels. In $u l p 2$ mutant cells, the R4 ULP1 domain was able to complement the mutation at both high and low expression levels. Yeast cells were grown for 3 days before they were photographed. 
NAC, and PLATZ transcription factors were significantly overrepresented among genes differentially expressed in response to Rppl silencing (corrected $P<0.01$ ). Of the 43 WRKY transcription factors identified, 12 were repressed ( $\log _{2} \mathrm{FC}$ from -1.73 to -3.32 ) by Rppl silencing, including homologs of AtWRKY transcription factors 6, 15, 40, 50, 51, and 70. Induced WRKY factors ( $\log _{2} \mathrm{FC}$ from 1.39 to 6.94 ) included homologs of AtWRKY factors 6, 23, 28, 30, 33, 40, $41,42,57,65,72$, and 75. WRKY transcription factors are associated with abiotic stress tolerance (WRKY factors 6, 30, $33,40,41,42,57,72,75)$ and biotic stress responses (WRKY factors 6, 28, 33, 40, 72) (Bakshi and Oelmüller 2014; Phukan et al. 2016). Glyma.13G310100, a homolog of AtWRKY6, was identified by Pandey et al. (2011) as required for Rpp2mediated resistance to Asian soybean rust. Glyma.13G310100 was induced by Rppl silencing with a $\log _{2} \mathrm{FC}$ of 3.46 .

\section{DISCUSSION}

The BPMV-based VIGS system has proven to be a powerful tool for analyzing soybean genes involved in both the recognition event and downstream signaling that occurs during the resistance response to $P$. pachyrhizi. Examples of this include the identification of Rpp4 (Meyer et al. 2009; Morales et al. 2013) and the functional analysis of genes involved in Rpp1and Rpp2-mediated responses (Cooper et al. 2013; Pandey et al. 2011). In this study, we employed VIGS to test candidate NBSLRR genes identified through sequencing BACs spanning the Rppl locus. The results presented here demonstrate that the soybean $R$ gene responsible for the IR to $P$. pachyrhizi encodes an NBS-LRR protein with an N-terminal ULP1 domain belonging to the $\mathrm{C} 48$ peptidase family.

Based on our previous VIGS work with Rpp4 (Meyer et al. 2009) and downstream Rpp2 signaling components (Pandey et al. 2011), we expected that silencing Rppl would yield a TAN phenotype with abundant uredinia, indicating complete susceptibility. However, our results suggest Rppl silencing altered the IR but not defense. There are three possible explanations for this unexpected phenotype. First, although silencing of the Rppl candidate genes greatly reduced the levels of Rppl candidate transcripts, VIGS is not absolute. Reduced levels of Rppl or components of the Rppl signaling pathway may condition a RB reaction rather than the IR. Expression levels of CcRppl, a $P$. pachyrhizi $R$ gene obtained from Cajanus cajan (pigeonpea), condition different degrees of resistance (Kawashima et al. 2016). Plants homozygous for CcRppl were immune to $P$. pachyrhizi and displayed no visible symptoms. However, hemizygous plants displayed a RB-type resistance. Expression analysis of the CcRppl transgene revealed greater expression in homozygous plants, suggesting that expression levels influenced the efficacy of the transgene (Kawashima et al. 2016). Although CcRppl is not orthologus to GmRpp1, it demonstrates that expression levels of $R$ genes can have a profound impact on the phenotype of resistance to SBR.

A second explanation for the observed $\mathrm{RB}$ phenotype in Rppl-silenced plants is that an additional gene may condition resistance to $P$. pachyrhizi in PI 200492. McLean and Byth (1980) were the first to demonstrate that Rppl segregated as a single locus in PI 200492. Similarly, Hyten et al. (2007) mapped Rppl as a single locus in L85-2378 (Rppl), an isoline

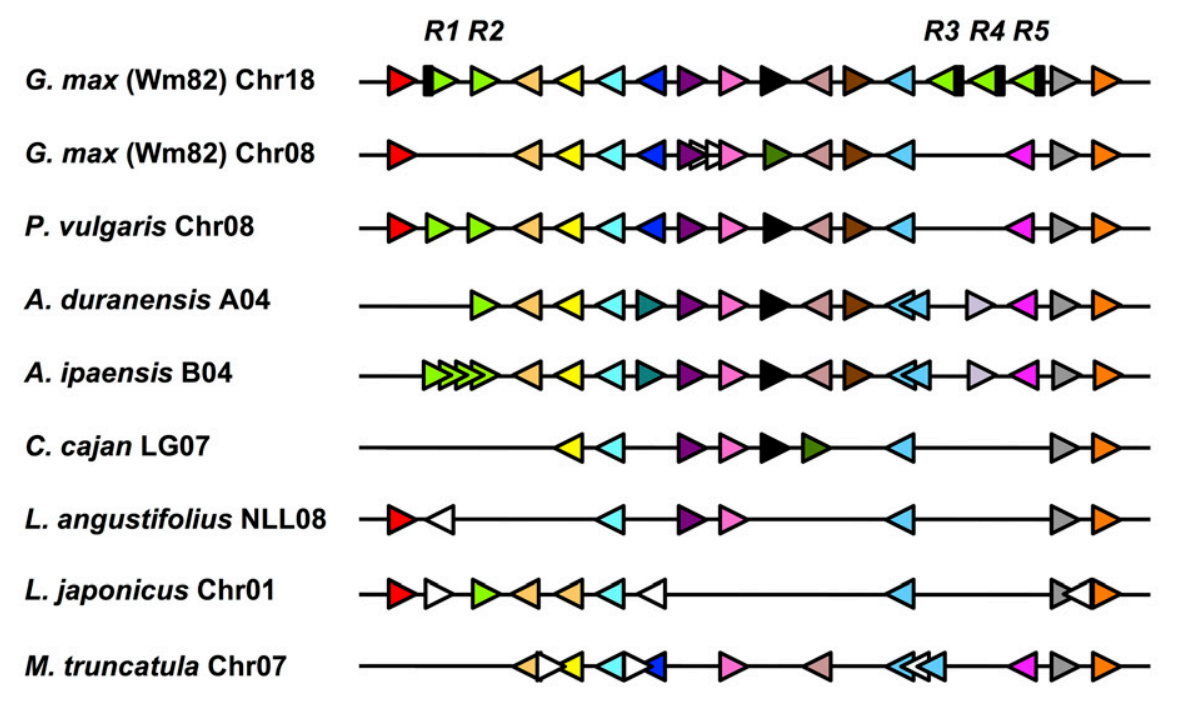

\begin{tabular}{|ll|}
\hline Protein Kinase & 60S Ribosomal Protein \\
ULP1-NBS-LRR & Acyl-CoA N-acetyltransferase \\
ULC-NBS-LRR & Ethylene-responsive Transcription Factor \\
COmeodomain Transcription Factor \\
Nuclear Matrix Protein & HTPase-activating Protein \\
Translation initiation Factor elF-2B & Calcium-dependent Phosphotriesterase \\
TCP transcription Factor & MEI2-like Protein \\
Devil 3 & PsaB RNA-binding Protein \\
Allene oxide cyclase & Calcium-binding EF Hand Protein \\
Unknown Protein & Species-specific Proteins \\
RNA Polymerase subunit RPAC2 & \\
\hline
\end{tabular}

Fig. 5. Evolution of the Rpp1 locus across legumes reveals the novel resistance (R) proteins unique to soybean. The Legume Information System Genomic Context Viewer (Dash et al. (2016) was used to examine the region corresponding to R1 through R5 in the Rppl locus (Gm18 from 56.10 to $56.30 \mathrm{Mb}$, version Wm82.a2.v1) across a broad range of legumes. The location and orientation of predicted genes is depicted by arrow heads. The color of the arrow head indicates sequence homology, a full description is provided in the box below the figure. To ease visualization, genes conserved across two or more species are aligned vertically. 
developed from Williams 82 and PI 200492 (Bernard et al. 1991). Silencing of the candidate Rppl genes in L85-2378 also compromised the IR (data not shown), suggesting no $R$ genes outside the Rppl locus contribute to rust resistance. However, the Rppl locus does contain multiple tightly linked $R$ genes. Chakraborty et al. (2009) mapped $R p p l b$ RB resistance in PI 594538 A to a region spanning the Rppl locus and recently Sahoo et al. (2017) mapped the Rps12 (Resistance to Phytophthora sojae 12) gene in PI 399036 to a 368-kb region encompassing the $R p p 1$ locus. Since silencing $R 3, R 4$, and $R 5$ compromised the IR but not defense to rust isolate LA04-1, a second $R$ gene in the Rppl locus would have to confer RB resistance to LA04-1 and not be silenced by our VIGS construct. This leaves $R 6$ and $R 7$ and additional $R$ genes near the $R p p l$ locus not spanned by our BAC contig as the most likely candidates for an additional rust $R$ gene. VIGS constructs developed from identical regions in $R 6$ and $R 7$ failed to compromise resistance, even when cosilenced with $R 3, R 4$, and $R 5$ (data not shown).

A third explanation is that Rppl confers a completely novel phenotype. This hypothesis is supported by the findings of Cooper et al. (2013), who reported disruption of Rpp1-mediated immunity following silencing of five different genes implicated in Rppl-mediated defense. While silencing resulted in small lesions associated with a HR and cell death, no sign of rust sporulation was detected, mirroring the Rppl-silencing phenotype. Further, PI 200492 has been tested with over 30 distinct $P$. pachyrhizi isolates representing geographical and temporal variation and only the IR or TAN phenotypes are observed (data not shown). Taken together these data suggest that no additional genes condition $\mathrm{RB}$ resistance to $P$. pachyrhizi in the Rppl locus but, instead, suggest silencing of Rppl results in a novel phenotype. Future experiments involving Rppl candidate transgene expression in a susceptible soybean background will hopefully shed light on these possibilities, demonstrating whether a single gene is sufficient to confer resistance and, if so, whether the level of transgene expression influences the resistance phenotype. Furthermore, complementation with Rppl candidate transgenes with inactive ULP1 domains should also provide evidence regarding the role of this domain in one or both recognition and signaling.
The unusual structure of Rpp1 raises several questions regarding how it functions in the resistance response. Specifically, does the ULP1 domain play a direct role in either recognition of the pathogen, downstream signaling following recognition, or, potentially, both events? Like other biotrophic plantpathogenic fungi, $P$. pachyrhizi delivers immunity-suppressing effector proteins inside the plant cell, via haustoria during the infection process, to promote virulence. Little is known regarding the effectors deployed by $P$. pachyrhizi, but several transcriptomic studies have identified potential candidates that are likely transferred into the host (de Carvalho et al. 2017; Kunjeti et al. 2016; Link et al. 2014). A small subset of these candidates have also been shown to promote virulence (Kunjeti et al. 2016), suppress the HR (de Carvalho et al. 2017), or suppress plant immunity (Qi et al. 2016; Qi et al. 2018). Although a cognate effector protein that triggers Rppl-mediated resistance has yet to be discovered, the Rpp1 ULP1 domain may serve as a useful tool for the identification of at least one.

Plant NBS-LRR proteins have evolved to detect pathogen effectors inside the host cell, either by direct or indirect recognition. In direct recognition, an effector directly binds to the NBS-LRR protein, which triggers a response by the host cell. In indirect recognition, the NBS-LRR protein monitors one or more host proteins acted upon by the effector. If a host protein targeted by the effector plays a role in immunity it is called a 'guardee' (Dangl and Jones 2001), and, in cases in which the host protein mimics the authentic host protein targeted by the effector, it is referred to as a 'decoy' (van der Hoorn and Kamoun 2008). Recently, a new model that is an amalgam between direct and indirect recognition has been put forth. This new model, known as the 'integrated decoy' model, attempts to explain why some NBS-LRR proteins contain additional domains (Cesari et al. 2014). The authors of this model propose that some host proteins targeted by effectors have been incorporated through evolution into NBS-LRR proteins, allowing for direct recognition of effector proteins.

Although originally thought to be rather anomalous, the presence of additional integrated domains within NBS-LRR proteins appears to be widespread throughout all plant lineages (Cesari et al. 2013; Kroj et al. 2016; Sarris et al. 2016). In their

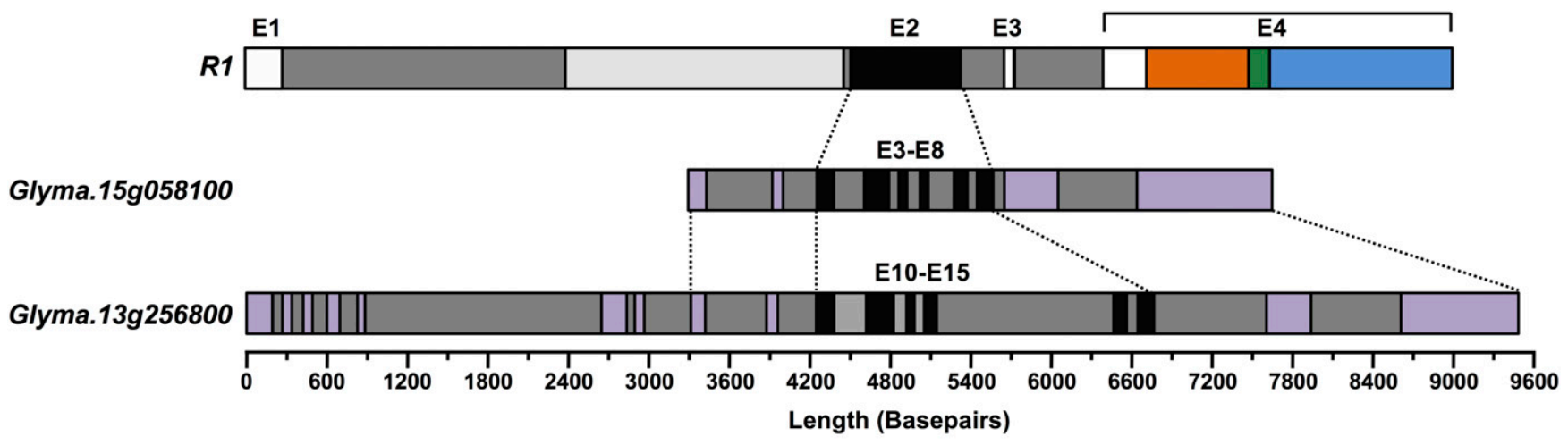

\begin{tabular}{|ll|}
\hline$\square$ Conserved R-gene Domains & $\square$ Intron \\
$\square$ NB-ARC & Ulp1 Protease \\
$\square$ Winged helix-turn-helix & $\square$ Other Conserved Domains \\
$\square$ LRR & $\square$ Copia Retroelement \\
\hline
\end{tabular}

Fig. 6. Characterization of the ULP1 domains in the Rppl candidate genes. BLASTN comparing the ULP1 domains from $R 1, R 3, R 4$, and $R 5$ to all predicted transcripts in the Williams 82 reference genome identified best matches to homeologous genes Glyma.13g256800 (E < 0.0) and Glyma.15g058100 (E < 10E-17). While the ULP1 domain is encoded by a single exon in the Rpp1 candidate genes, it corresponds to six exons in Glyma.13g256800 and Glyma.15g058100. Lack of introns in the ULP domains of the Rppl candidate genes suggests the ULP1 domain was inserted into an ancestral resistance ( $R$ ) gene by a retrotransposition event between exons 1 and 2 . BLASTN analyses identified a Copia retroelement in intron 1 of $R 1$, immediately preceeding the ULP1 domain. 
search of 40 publicly available plant predicted proteomes, Sarris et al. (2016) identified 61 distinct Pfam domains that occur in at least two different plant families. This group includes the ULP1 protease domain (called a Peptidase_C48 domain by Sarris et al. [2016]), which was found in NBS-LRR proteins in soybean, Fragaria vesca, and Zea mays. With the exception of soybean genes, presented in this study, these genes have not been demonstrated to play a role in defense. Nevertheless, it has been suggested that the mere presence of the same integrated domain in different plant species is an indication that these hosts may be attacked by pathogens that attempt to manipulate similar host proteins (Malik and Van der Hoorn 2016). This hypothesis is consistent with the findings of Mukhtar et al. (2011) and Wessling et al. (2014) that demonstrate effectors from diverse pathogens may target common host proteins. We hypothesize that the ULP1 domain of Rpp1 functions as an integrated decoy and that one or more components of the sumoylation machinery may be targeted by P. pachyrhizi effectors.

The Rpp1 ULP1 domain most closely resembles proteases involved in sumoylation. Sumoylation is a rapid and reversible posttranslational modification conserved in all eukaryotic organisms, involving the conjugation of a SUMO peptide to a protein. The presence or absence of SUMO on a particular protein can alter its stability, interaction with other proteins, localization, or enzymatic activity, and there is an increasing body of evidence showing that sumoylation plays a key role in plant immunity (Verma et al. 2018). Among the first studies implicating sumoylation in plant-pathogen interactions was the discovery that XopD, a Xanthomonas campestris pv. vesicatoria effector protein, which is a SUMO protease with plantspecific SUMO substrate specificity (Hotson et al. 2003). During infection XopD is delivered inside the plant cell, via the bacterial type III secretion system, in which it mimics plant SUMO isopeptidases. This finding demonstrates that pathogens likely target SUMO-dependent processes in their attempts to thwart host defenses.

Forward and reverse genetic approaches have also identified components of the SUMO machinery that participate in plant defense responses (Bailey et al. 2016; Castaño-Miquel et al. 2017; Gou et al. 2017; Lee et al. 2007; van den Burg and Takken 2010). The sizl E3 SUMO ligase mutant in Arabidopsis exhibits constitutive systemic-acquired resistance (SAR) with elevated levels of salicylic acid (SA) and increased pathgenesisrelated $(P R)$ genes (Lee et al. 2007). Interestingly, downregulation of soybean GmSIZla and GmSIZlb using RNA interference-mediated gene silencing did not significantly alter SA levels (Cai et al. 2017), leaving open the possibility that other E3 SUMO ligases may play a role in SAR in soybean. NPR1, a central regulator of SAR, was recently shown to be sumoylated upon immune induction by SA. Sumoylation of NPR1 altered its association with WRKY transcriptional repressors to TGA transcriptional activators (Saleh et al. 2015). Sumoylation of specific transcription factors, including WRKYs, may also serve to suppress the expression of early defense genes that are then rapidly activated through mitogen-activated protein kinase (MAPK) signaling cascades in response to MTI or ETI (van den Burg and Takken 2010). Together, SUMO and MAPK signaling may provide dynamic control over plant immune responses (van den Burg and Takken 2010). Significantly, silencing of GmNPR1 and GmWRKY 36, GmWRKY 40, and $G m W R K Y 45$ were shown to compromise Rpp2-mediated resistance (Pandey et al. 2011).

Since independently evolved effectors from diverse pathogens target common host proteins or 'hub proteins' (Mukhtar et al. 2011; Wessling et al. 2014), it is reasonable to assume that enzymes involved in sumoylation, including the SUMO proteases that remove SUMO peptides from other proteins, are ideal targets for effectors that compromise MTI or ETI. Although we are unaware of any SUMO proteases that are targeted by plant pathogens, several fungal and oomycete effectors have been shown to exhibit protease inhibition (Pretsch et al. 2013; Tian et al. 2007; van Esse et al. 2008). RTP1 from the rust fungi Uromyces fabae and Uromyces striatus were the first fungal proteins shown to be specifically expressed in haustoria and transferred to the host cytoplasm during infection (Kemen et al. 2005). More recently the C-terminal domain of RTP1 was shown to have similarity to the $\mathrm{C}$-terminal domain of cysteine protease inhibitors (Pretsch et al. 2013). RTP1 homologs have now been identified in several rust fungi, including two from P. pachyrhizi (Pretsch et al. 2013). The putative targets of PpRTP1 and PpRTP2 are not known but this indicates that P. pachyrhizi deploys protease inhibitors as part of its effector repertoire.

An additional inference that can be drawn from the integrated decoy model is that incorporated proteins may eventually lose their biochemical activity while retaining effector-binding properties (Maqbool et al. 2015). Analysis of protein kinases fused to NBS-LRR proteins, the most common class of integrated domains, revealed that most kinases identified as integrated domains are potentially catalytically active (Sarris et al. 2016). This suggests that integrated domains originating from proteins with enzymatic activity may not act merely as decoys; rather, such domains may retain their original function and serve as integrated sensors (Sarris et al. 2016). Our analysis of the genes at the Rppl locus is consistent with this assertion, as the predicted proteins encoded by these genes all retain the conserved protease catalytic residues and expression of the ULP1 domain of $R 4$ and $R 5$ were shown to complement the yeast ULP mutants.

Further studies are needed to determine if the enzymatic activity of Rpp1 is required for the IR. If the protease activity is required and assuming that disruption of the activity does not alter its interaction with a putative effector, then, this would be an indication that the ULP1 domain functions in signal transduction. In this scenario, the ULP1 domain would become activated following the recognition event, which would lead to the desumoylation of one or more downstream proteins leading to the IR. If the protease activity turns out to be dispensable for resistance, then, the ULP1 domain of Rpp1 may have a function independent of resistance. The fact that the Williams 82 susceptible soybean line retains the ULP1 domains at this locus would argue that there may be a selective advantage to retaining this activity.

In previous experiments, we used microarray analysis to compare gene expression in control and Rpp4-silenced plants (Meyer et al. 2009). Unlike Rppl, Rpp4 contained no predicted integrated domains. Of the 264 differentially expressed genes responding to Rpp4 silencing, 7.2\% (19 of 264) were induced. In contrast, $32.1 \%(1,211$ of 3,777$)$ of differentially expressed genes were induced in response to Rppl-silencing, suggesting the ULP1 domain found in $R 1, R 3, R 4$, and $R 5$ could impact gene expression. The Arabidopsis genome contains eight predicted ULPs: OTS1/ULP1D (At1g60220), OTS2/ULP1C (At1g10570), ELS1/ULP1A (At3g06910), ESD4 (At4g15880), $A S P 1 / S P F 1 / U L P 2 B$ (At1g09730), ULP1B (At4g00690), SPF2/ULP2A (At4g33620), and At3g48480 (Conti et al. 2008; Kong et al. 2017; Novatchkova et al. 2012; Reeves et al. 2002). OTS1, OTS2, ESD4, ELS1 and ASP1 regulate flowering time in Arabidopsis (Conti et al. 2008; Kong et al. 2017; Novatchkova et al. 2012; Reeves et al. 2002). OTS1 and OTS2 regulate responses to osmotic stress, light-induced signaling, and SAmediated signaling (Castro et al. 2016; Sadanandom et al. 2015). In addition, OTS1 is involved in transcriptional gene 
silencing and tolerance to high copper levels (Liu et al. 2017a; Zhan et al. 2018). ASP1, which is most closely related to the ULP1 domains present in $R 1, R 3, R 4$, and $R 5$, regulates flowering time, fertility, and abscisic acid signaling during seedling development (Kong et al. 2017; Liu et al. 2017b; Wang et al. 2018). Of the eight Arabidopsis ULPs identified, only an OTS1 and OTS2 double mutant (ulplc/ulpld) has been characterized using whole-genome expression analyses (Castro et al. 2016). In ulplc/ulp1d, 112 genes were differentially expressed relative to wild-type controls. Genes associated with abiotic and biotic stress responses were significantly overrepresented. Nineteen of these genes (corresponding to 41 soybean best-BLAST orthologs) were also differentially expressed in response to Rppl-silencing. However, none of the 41 soybean orthologs were differentially expressed in response to Rpp4-silencing, again suggesting a role for the ULP1 domain in $R 1, R 3, R 4$, and $R 5$. Included within the 19 genes common to ulplc/ulpld and Rppl-silencing were orthologs of Arabidopsis flowering-time genes (Flowering locus T [AtFT], Glyma.08G363100 and Glyma.16G150700) and AtFD (Glyma.04G022100), AtPSK5 (Glyma.09G277600 and Glyma. 18G21270), and AtWRKY28 (Glyma.02G285900, Glyma. 05G127600, and Glyma.14G028900). AtPKS5 phosporylates and interacts with NPR1 to regulate expression of defenserelated WRKY33 and WRKY62 (Xie et al. 2010). AtWRKY28 enhances tolerance to abiotic and biotic stress (Babitha et al. 2013; Chen et al. 2013). This suggests the ULP1 domain can modulate defense responses and helps explain the novel phenotype of Rppl-silenced plants.

Using a bioinformatic approach, Sarris et al. (2016) identified $\mathrm{R}$ proteins with integrated domains in 40 different plant species. Interestingly, integration of the same domain could be found in distinct plant lineages, indicating independent insertion events. The peptidase C48 domain, corresponding to the ULP1 domain, was reported in soybean, wild strawberry (Fragaria vesca, mrna24089.1.v1.0) and maize (Zea mays, GRMZM2G033519_P01). In strawberry, the peptidase C48 domain was located downstream of the LRR domain. In both soybean and maize, the peptidase C48 domain was located upstream of the NBS. In maize, the peptidase C48 domain of GRMZM2G033519_P01 contains multiple introns and exons. In contrast, the peptidase C48 domain corresponds to a single exon in soybean. This confirms independent integration of this domain in these three species. Given that all other ULP genes in the soybean genome contain at least four exons (Li et al. 2017) and the presence of a Copia element immediately preceeding the ULP1 domain in $R 1$, it seems likely the ULP1 domain was inserted into the first intron of an ancestral gene at the Rppl locus by readthrough transcription from a retroelement. Hoen et al. (2006) demonstrated that a family of ULP-like genes (97 genes and pseudogenes) had expanded in the genome of Arabidopsis through the action of Mutator-like transposable elements. Further, transduplicated genes were under selective pressure to maintain their function. ULP domains have also been identified in transposable elements from diverse species including grape (Benjak et al. 2008), melon, and rice (van Leeuwen et al. 2007) and from the soybean oomycete pathogens Phytophthora sojae and Phytophthora ramorum (Kojima and Jurka 2011).

The identification of Rpp1 as a novel ULP1-NBS-LRR advances our understanding of the molecular basis of resistance employed by soybean against $P$. pachyrhizi and has allowed us to formulate new hypotheses to further explore this important pathosystem. For example, although many putative $P$. pachyrhizi effectors have been identified, little is known concerning their targets within the cell. The Rpp1 ULP1 domain may represent a key target of $P$. pachyrhizi effectors, which would provide additional support for the sumoylation pathway as an essential component of immunity toward microbial pathogens. Further investigation into the role of the Rpp1 ULP1 domain is an important future goal that should provide additional insight into the soybean defense mechanisms and $P$. pachyrhizi virulence determinants.

\section{MATERIALS AND METHODS}

\section{Plant materials.}

The resistant soybean accession PI 200492 (Rpp1) (McLean and Byth 1980) and the susceptible genotype Williams 82 (Hyten et al. 2007) were used in this study. Seeds were germinated in a growth chamber at $20^{\circ} \mathrm{C}$ with a 16 -h photoperiod. Plants were fertilized with Peters Professional 20-20-20 General Purpose (Everris NA Inc.) at 3 weeks following germination.

\section{Sequencing of the Rpp1 locus.}

A BAC library of the resistant soybean accession PI 200492 (Rppl) was constructed from high molecular weight genomic DNA isolated from $10 \mathrm{~g}$ of young leaf tissue by Bio S\&T Inc. (Montreal, Canada). The genomic DNA was partially digested with HindIII, was cloned into pIndigo BAC (HindIII) (Epicentre Inc.), and was transformed into Escherichia coli DH10B (Invitrogen). Estimated genome coverage was $10 \times$ with an average insert size of $130 \mathrm{~kb}$. The library was screened by PCR according to the manufacturer recommendations, with primers designed to amplify DNA sequences located at the Rppl locus. Four BACs (PI_200492_1C06, PI_200492_2G03, PI _200492_1A02, and PI_200492_2E10) were identified and were used to construct shotgun libraries. Briefly, DNA was extracted from Escherichia coli, using the Qiagen largeconstruct kit (Qiagen). The recovered DNA was sheared and cloned, using the TOPO Shotgun subcloning kit (Invitrogen, Thermo Fisher Scientific). DNA sequencing of subclones from BACs PI_200492_1A02 and PI_200492_2E10 was performed by Eurofins MWG Operon LLC. DNA sequencing of subclones from BACs PI 200492_1C06 and PI_200492_2G03 was performed in-house at the United States Department of Agriculture Agricultural Research Service Corn Insects and Crop Genetics Research (USDA-ARS CICGRU) facility. All sequencing was performed using an Applied Biosystems 3730 DNA Analyzer with a 96-capillary array. Sequences were trimmed and assembled using Sequencher version 5.4, with the default parameters, with the exception of a minimum match percentage of $100 \%$ (Gene Codes Corp.) and a 100-bp overlap. To maximize read lengths and improve assembly accuracy, forward and reverse reads for the same subclone were preassembled prior to BAC assembly. Each BAC was assembled individually, prior to assembly of all BACs. The Williams 82 reference genome (version Williams82.a2.v1) (Schmutz et al. 2010) was used to orient contigs when necessary to fill gaps. Gaps were filled, using PCR, to amplify from the BAC in question. PCR products were cloned and sequenced at the USDA-ARS CICGRU facility, using Hi-Fi Platinum Taq DNA polymerase (Invitrogen), a TA cloning kit (Invitrogen), and One Shot TOP10 electrocompetent Escherichia coli (Invitrogen).

\section{Annotation of the Rpp1 locus in PI 200492.}

The sequence from the Rppl contig from PI 200492 (324,316 bp, GenBank accession MH590229) was divided into 2,000-bp intervals that were compared with the UniProt (Apweiler et al. 2004) and TAIR (version 10) protein databases, using BLASTX (Altschul et al. 1997) to identify potential protein coding sequences. In addition, BLASTN (Altschul et al. 1997) was used to compare against predicted genes and 
transcripts from the Williams 82 reference genome (Schmutz et al. 2010). FGENESH (Solovyev et al. 2006) and the NetPlantGene2 Server (Hebsgaard et al. 1996) analyses were used to predict exon positions and splice sites within candidate genes of interest. InterProScan (Jones et al. 2014) was used to identify conserved domains within predicted protein sequences of interest. BLASTN (Altschul et al. 1997) against the SoyTE database (Du et al. 2010) was used to search for transposable elements within the Rppl candidate genes.

\section{Evolutionary analyses of the Rpp1 locus across legumes.}

To examine the evolution of the Rppl locus across sequenced legume species, we took advantage of the Legume Information System Genomic Context Viewer (Dash et al. 2016). We used the sequence from the Rppl locus in PI_200492 to identify the corresponding region in the Williams 82 reference genome (Gm18 from 56.10 to $56.30 \mathrm{Mb}$, version Wm82.a2.v1) (Schmutz et al. 2010), the homeologous region on Gm08 (22.28 to 23.15 $\mathrm{Mb}$ ) of soybean and syntenic regions from Phaseolus vulgaris (Pv08: 1.65 to $1.83 \mathrm{Mb}$, genome version 2.0) (Schmutz et al. 2014), Arachis duranensis (A04: 120.49 to $121.05 \mathrm{Mb}$, genome version 1.0) (Bertioli et al. 2016), Arachis ipaensis (B04: 130.67 to $131.29 \mathrm{Mb}$, genome version 1.0) (Bertioli et al. 2016), Cajanus cajan (LG07: 16.70 to $16.79 \mathrm{Mb}$, genome version 1.0) (Varshney et al. 2012), Lupinus angustifolius (NLL08: 1.99 to $2.16 \mathrm{Mb}$, genome version 1.0) (Hane et al. 2017), Lotus japonicus (Chr01: 35.40 to $35.68 \mathrm{Mb}$, genome version 2.5) (Sato et al. 2008), and Medicago truncatula (Chr07:5.93 to $6.60 \mathrm{Mb}$, genome version 4.0) (Tang et al. 2014). To determine if $\mathrm{R}$ proteins with ULP1 domains were present in any of these species, we divided each of the predicted protein sequences of $R 1, R 3, R 4$, and $R 5$ into two sections, one containing the ULP1 domain and the other containing the remaining protein sequence. BLASTP (Altschul et al. 1997) was used to compare each of these sections to all predicted proteins from soybean, Phaseolus vulgaris, Arachis duranensis, Arachis ipaensis, Cajanus cajan, Lupinus angustifolius, Lotus japonicus, and Medicago truncatula. BLAST reports of the two regions were compared to identify any putative $\mathrm{R}$ proteins with a ULP1 domain in any species.

\section{P. pachyrhizi inoculations.}

P. pachyrhizi inoculum was prepared as previously described (Kendrick et al. 2011), using isolate LA04-1, which elicits an IR with soybean PI 200492 (Rppl) but is fully pathogenic on the susceptible Williams 82 (Ray et al. 2009). Spore concentrations were measured with a hemacytometer and were adjusted to approximately $5.0 \times 10^{4}$ spores $\mathrm{ml}^{-1}$ in a solution of $0.01 \%$ Tween 20 in sterile distilled water. Inoculum was applied with an atomizer until leaves were saturated. Plants were incubated in a $20^{\circ} \mathrm{C}$ dew chamber overnight, then transferred to a $25^{\circ} \mathrm{C}$ greenhouse.

\section{VIGS of Rpp1 candidate genes.}

A DNA fragment representing an identical 234-bp region of $R 3, R 4$, and $R 5$ was synthesized from overlapping oligonucleotides KP863, KP864, KP865, and KP866. Briefly, $2 \mu \mathrm{M}$ of each oligonucleotide was reacted in PCR buffer with $0.2 \mathrm{mM}$ dNTPs and $1 \mathrm{U} \mathrm{Taq}$ polymerase, with an initial denaturation step at $94^{\circ} \mathrm{C}$ for $2 \mathrm{~min}$, followed by five PCR cycles $\left(94^{\circ} \mathrm{C}\right.$ for $1 \mathrm{~min}, 50^{\circ} \mathrm{C}$ for $30 \mathrm{~s}$, and $72^{\circ} \mathrm{C}$ for $1 \mathrm{~min}$ ), followed by a 2 -min extension at $72^{\circ} \mathrm{C}$. One microliter of the reaction was used as template for PCR under the same conditions with 20 cycles, using oligonucleotides KP867 and KP868 to generate BamHI and $K p n I$ sites for directional cloning into pBPMV-R2. Orientation of the insert was confirmed by sequencing, using a vector-specific forward primer 1548F (Zhang et al. 2009). To generate inoculum for VIGS experiments, BPMV RNA1
(pBPMV-IA-R1M) and either the Rppl experimental (pBPMV$R p p 1$ ) or a GFP control (pBPMV-GFP) plasmid were coinoculated via particle bombardment on leaves of Williams 82 plants at 14 days after sowing, as previously described (Whitham et al. 2016; Zhang et al. 2009, 2010). Symptomatic BPMV-infected leaf tissue was collected three to five weeks after bombardment, were lyophilized, and were stored at $-20^{\circ} \mathrm{C}$.

Two weeks after germination, primary leaves of PI 200492 (Rppl) plants were dusted with Carborundum and were rubinoculated with lyophilized BPMV-infected leaf tissue that was ground to a powder and was suspended in $50 \mathrm{mM}$ potassium phosphate buffer, $\mathrm{pH}$ 7.0. Plants were transferred to the USDA BSL-3 plant pathogen-containment facility at Fort Detrick (Melching et al. 1983) approximately five weeks after BPMV inoculation. BPMV-infected plants were inoculated with $P$. pachyrhizi and were assessed for SBR symptoms 2 weeks after inoculation. For each experiment, six plants inoculated with each BPMV construct were used. Three independent replicates of the experiment were performed.

\section{Assessment of gene silencing and fungal growth in VIGS plants.}

To assess Rppl candidate gene silencing, 1-cm diameter leaf disks were removed from the fourth trifoliate of BPMVinfected plants 2 weeks after inoculation with $P$. pachyrhizi. Collected tissue was immediately frozen in liquid nitrogen and was stored at $-80^{\circ} \mathrm{C}$. Leaf tissue was ground in liquid nitrogen and RNA was extracted, using the Qiagen Plant RNeasy kit (Qiagen), and was treated with Turbo DNase (Ambion, Thermo Fisher Scientific). First-strand cDNA synthesis was performed with the Transcriptor first-strand cDNA synthesis kit (Roche). qRT-PCR was performed on cDNA derived from experimental and control plants, using Rppl candidate-specific oligonucleotide primers KP920 and KP921 and probe KP922 modified with 6-carboxy fluorescein at the $5^{\prime}$ end and with Blackhole Quencher I at the $3^{\prime}$ end (Integrated DNA Technologies), using a 120 -s denaturation step at $95^{\circ} \mathrm{C} \mathrm{s}$, followed by 40 PCR cycles $\left(95^{\circ} \mathrm{C}\right.$ for $15 \mathrm{~s}$ and $68^{\circ} \mathrm{C}$ for $\left.60 \mathrm{~s}\right)$. Fungal growth was assessed by measuring the constitutively expressed P. pachyrhizi $\alpha$-tubulin gene, by qRT-PCR using primers KP1045 and KP1046, using a 90 -s denaturation step followed by 40 reaction cycles $\left(95^{\circ} \mathrm{C}\right.$ for $15 \mathrm{~s}, 60^{\circ} \mathrm{C}$ for $30 \mathrm{~s}$, and $72^{\circ} \mathrm{C}$ for $\left.30 \mathrm{~s}\right)$. Soybean Rppl and $P$. pachyrhizi $\alpha$-tubulin transcript levels were normalized to the soybean ubiquitin-3 gene (GenBank accession number D28123), using a 120 -s denaturation at $95^{\circ} \mathrm{C}$ followed by 40 reaction cycles $\left(95^{\circ} \mathrm{C}\right.$ for $15 \mathrm{~s}, 52^{\circ} \mathrm{C}$ for $30 \mathrm{~s}$, and $72^{\circ} \mathrm{C}$ for $\left.30 \mathrm{~s}\right)$. The ubiquitin-3 gene is not differentially expressed during $P$. pachyrhizi infection (van de Mortel et al. 2007). Three experimental replicates were performed for both qRT-PCR experiments, using three independent biological replicates.

\section{Gene expression of Rppl candidate genes.}

To measure the expression of Rppl candidate genes $R I$ through R5, we used ClustalW (Larkin et al. 2007) to align predicted RNA transcripts from PI 200492 and Williams 82. We identified an approximately 300 -bp region within the NBS domain that was highly conserved across all $R$ genes in the Rppl locus from PI 200492 and Williams 82. Primers were designed from regions identical across all genes. Amplified products varied in size and contained unique sequence differences that could be used to identify the corresponding genes. To measure amplification efficiency for each of the genes, the primers were tested on genomic DNA of PI 200492 and Williams 82. Reaction conditions included a 90 -s denaturation step at $94^{\circ} \mathrm{C}$, followed by $35 \mathrm{PCR}$ cycles $\left(94^{\circ} \mathrm{C}\right.$ for $30 \mathrm{~s}, 54^{\circ} \mathrm{C}$ for $30 \mathrm{~s}$, and $72^{\circ} \mathrm{C}$ for $60 \mathrm{~s}$ ) and a $72^{\circ} \mathrm{C}$ extenstion for $120 \mathrm{~s}$. PCR amplicons were cloned into pCR2.1-TOPO (Invitrogen, Thermo Fisher 
Scientific) and were transformed into TOP10 Electrocomp Escherichia coli (Invitrogen, Thermo Fisher Scientific). Cloned DNA was prepared and sequenced at the USDA-ARS CICGRU facility as described above. Sequences were imported into Sequencher version 5.4 (Gene Codes Corp.) and vector sequences and low-quality sequences were trimmed. Sequences were aligned by clone pair, and consensus sequences were compared with the Rppl locus in PI 200492 and Williams 82, using BLASTN (Altschul et al. 1997) to remove nontarget genes. Gene-specific nucleotide differences were used to assign subclones to specific genes. Paired sequences of more than 100 genomic clones from each genotype were used to determine an application efficiency correction factor for $R p p l R l$ to $R 5$ in each genotype. Individual gene representation was determined by dividing the number of clones assigned to each gene by the total number of assigned clones overall. An amplification efficiency correction factor was then determined for each gene in each genotype by dividing expected representation by observed representation. Since the primers matched all genes perfectly and there were five genes in each genotype, expected representation was 0.2 for all genes.

To measure baseline Rppl Rl to $R 5$ gene expression in resistant and susceptible plants, the second trifoliate leaves were collected from noninoculated PI 200492 and Williams 82. To measure Rppl candidate gene expression in response to $P$. pachyrhizi, tissue was collected from mock-inoculated and infected plants 24 and $72 \mathrm{~h}$ after inoculation. Collected tissue was immediately frozen in liquid nitrogen and was stored at $-80^{\circ} \mathrm{C}$. Leaf tissue was ground in liquid nitrogen and RNA was extracted using the Qiagen Plant RNeasy kit (Qiagen) and was treated with Turbo DNase (Ambion, Thermo Fisher Scientific). First-strand cDNA synthesis was performed with the Transcriptor first-strand cDNA synthesis kit (Roche). cDNAs were amplified with PCR primers KP1041 and KP1042 and were cloned, sequenced, and analyzed as described above. To correct expression for differences in amplification efficiency, the number of observed clones for a given cDNA was multiplied by the correction factor determined for each given gene above.

\section{Experiments in yeast.}

Yeast strains TSA566 (MATa, ura3 $\Delta 0$, leu2 $\Delta 0$, his $3 \Delta 1$, met15 $\Delta$, ulp1-333:kanMX) and Y21424 (MATa/MAT $\alpha$, ura3 $\Delta 0 /$ ura $3 \Delta 0$, leu2 $\Delta 0 /$ leu $2 \Delta 0$, his $3 \Delta 1 /$ his $3 \Delta 1$, met15 $\Delta 0 /$ MET15, LYS2/lys2 $\Delta 0$, YIL031w/YIL031w::kanMX4) were obtained from the European Saccharomyces cerevisiae Archive for Functional Analysis database. A haploid derivative of Y21424, AR01, was obtained via random spore analysis, following standard protocols (Treco and Winston 2008), and was screened for lysine and methionine auxotrophic traits and the Ulp2 deletion phenotype. Mutations in TSA566 (ulp1) and AR01 (ulp2) cause temperature sensitivity of growth. For complementation studies, TSA566 and AR01 were transformed with the ULP1 domains of $R 3, R 4$, or $R 5$, driven by the galactose-inducible promoter $\mathrm{P}_{G A L 1}$ or its weaker derivative $\mathrm{P}_{G A L S}$, in the CEN6/ URA3-based plasmids p416GAL1 and p416GALS, respectively (Mumberg et al. 1994). In addition, an inactive version of the $R 4$ ULP1 domain containing a mutation in the catalytic triad (C310S) was also expressed. Plasmids p416GAL1 and p416GALS were obtained from the American Type Culture Collection database. Open reading frames of the native $R 3, R 4$, and $R 5$ ULP1 domains and mutant $R 4$ ULP1 domain, each modified to include an $\mathrm{N}$-terminal myc tag, were synthesized by GenScript, were excised from pUC57-Simple as XbaI/SalI fragments, and were cloned into XbaI/SalI digested p416GAL1 and p416GALS vectors. Transformed yeast cells were recovered on synthetic defined (SD) (-ura) media with glucose as the sole carbon source at $30^{\circ} \mathrm{C}$. To test for complementation, cells were grown overnight at $30^{\circ} \mathrm{C}$ in liquid SD (-ura) glucose media and were streaked onto SD (-ura) glucose or SD (-ura) galactose/rafinose media followed by incubation at 30 or $37^{\circ} \mathrm{C}$ for 3 days.

\section{RNA-seq analyses of VIGS plants.}

The six RNA samples used to confirm VIGS silencing were also used for RNA-seq analyses. Prior to RNA-seq, samples were purified and were concentrated using the Qiagen RNeasy MinuElute cleanup kit (Qiagen). The Agilent 2100 Bioanalyzer (Agilent) was used to confirm an RNA integrity number greater than seven. RNA-seq library preparation and 150-bp single end sequencing was performed at the Iowa State University DNA facility, using the Illumina HiSeq 2500 platform (Illumina). Following sequencing, reads from individual libraries were trimmed to remove adaptor sequences, sequencing artifacts and low-quality sequences, as described by Atwood et al. (2014). Tophat version 2.1.1 (Trapnell et al. 2009) was used to align reads to the Williams 82 reference genome sequence (Wm82. a2.v1) (Schmutz et al. 2010). Samtools (Li et al. 2009) was used to remove unreliably mapped reads. The resulting mapping files were imported in the statistical program R (R Core Team 2014), using Rsamtools (Morgan and Pages 2013). Gene correspondences were made using the Williams82.a2.v1 gene feature file, imported using rtracklayer (Lawrence et al. 2009). Mapped reads per gene per sample were counted using Genomic Alignments (Lawrence et al. 2013). The $\mathrm{R}$ graphics program ggplot2 (Wickham 2009) was used to compare and visualize counts for sample replicates for technical reproducibility. One vector control sample was removed from further analysis.

Prior to data normalization and statistical analysis of differentially expressed genes, counts assigned $R 3, R 4$, and $R 5$ were removed, as they were likely of viral origin. However, the high counts did confirm presence of the virus in silenced plants. All genes with counts per million $<1$ across all biological replicates were removed from further analysis. EdgeR (Robinson et al. 2010) was used for single factor, pairwise comparisons to calculate normalization factors and to identify differentially expressed genes, using a FDR $<.001$. DEGs were annotated using the SoyBase database Genome Annotation Report page which provided best Arabidopsis thaliana homologs and inferred GO information (TAIR version 10). Significantly (corrected $P$ value $<0.05$ ) overrepresented biological process GO terms were identified using the SoyBase GO Term Enrichment tool. Differentially expressed transcription factors were identified using The SoyDB transcription factor database (Wang et al. 2010).

\section{ACKNOWLEDGMENTS}

We thank A. Luquette and W. Lane for their technical assistance.

\section{LITERATURE CITED}

Aarts, N., Metz, M., Holub, E., Staskawicz, B. J., Daniels, M. J., and Parker, J. E. 1998. Different requirements for EDS1 and NDR1 by disease resistance genes define at least two $R$ gene-mediated signaling pathways in Arabidopsis. Proc. Natl. Acad. Sci. U.S.A. 95:10306-10311.

Altschul, S. F., Madden, T. L., Schäffer, A. A., Zhang, J., Zhang, Z., Miller, W., and Lipman, D. J. 1997. Gapped BLAST and PSI-BLAST: A new generation of protein database search programs. Nucleic Acids Res. 25:3389-3402.

Apweiler, R., Bairoch, A., Wu, C. H., Barker, W. C., Boeckmann, B., Ferro, S., Gasteiger, E., Huang, H., Lopez, R., Magrane, M., Martin, M. J., Natale, D. A., O'Donovan, C., Redaschi, N., and Yeh, L. S. 2004. UniProt: The universal protein knowledgebase. Nucleic Acids Res. 32:D115-D119.

Atwood, S. E., O'Rourke, J. A., Peiffer, G. A., Yin, T., Majumder, M., Zhang, C., Cianzio, S. R., Hill, J. H., Cook, D., Whitham, S. A., Shoemaker, R. C., and Graham, M. A. 2014. Replication protein A subunit 3 and the iron efficiency response in soybean. Plant Cell Environ. 37:213-234. 
Babitha, K. C., Ramu, S. V., Pruthvi, V., Mahesh, P., Nataraja, K. N., and Udayakumar, M. 2013. Co-expression of AtbHLH17 and AtWRKY28 confers resistance to abiotic stress in Arabidopsis. Transgenic Res. 22: 327-341.

Bailey, M., Srivastava, A., Conti, L., Nelis, S., Zhang, C., Florance, H., Love, A., Milner, J., Napier, R., Grant, M., and Sadanandom, A. 2016. Stability of small ubiquitin-like modifier (SUMO) proteases OVERLY TOLERANT TO SALT1 and -2 modulates salicylic acid signalling and SUMO1/2 conjugation in Arabidopsis thaliana. J. Exp. Bot. 67:353-363.

Bakshi, M., and Oelmüller, R. 2014. WRKY transcription factors: Jack of many trades in plants. Plant Signal. Behav. 9:e27700.

Benjak, A., Forneck, A., and Casacuberta, J. M. 2008. Genome-wide analysis of the "cut-and-paste" transposons of grapevine. PLoS One 3: e3107.

Bernard, R. L., Nelson, R. L., and Cremeens, C. R. 1991. USDA soybean genetics collection: Isoline collection. Soybean Genet. Newsl. 18:27-57.

Bertioli, D. J., Cannon, S. B., Froenicke, L., Huang, G., Farmer, A. D., Cannon, E. K. S., Liu, X., Gao, D., Clevenger, J., Dash, S., Ren, L., Moretzsohn, M. C., Shirasawa, K., Huang, W., Vidigal, B., Abernathy, B., Chu, Y., Niederhuth, C. E., Umale, P., Araújo, A. C. G., Kozik, A., Kim, K. D., Burow, M. D., Varshney, R. K., Wang, X., Zhang, X., Barkley, N., Guimarães, P. M., Isobe, S., Guo, B., Liao, B., Stalker, H. T., Schmitz, R. J., Scheffler, B. E., Leal-Bertioli, S. C. M., Xun, X., Jackson, S. A., Michelmore, R., and Ozias-Akins, P. 2016. The genome sequences of Arachis duranensis and Arachis ipaensis, the diploid ancestors of cultivated peanut. Nat. Genet. 48:438-446.

Boller, T., and Felix, G. 2009. A renaissance of elicitors: Perception of microbe-associated molecular patterns and danger signals by patternrecognition receptors. Annu. Rev. Plant Biol. 60:379-406.

Bonde, M. R., Nester, S. E., Austin, C. N., Stone, C. L., Frederick, R. D., Hartman, G. L., and Miles, M. R. 2006. Evaluation of virulence of Phakopsora pachyrhizi and P. meibomiae isolates. Plant Dis. 90:708-716.

Bromfield, K. R. 1984. Soybean Rust. Monogr. No. 11. American Phytopathological Society, St. Paul, MN, U.S.A.

Cai, B., Kong, X., Zhong, C., Sun, S., Zhou, X. F., Jin, Y. H., Wang, Y., Li, X., Zhu, Z., and Jin, J. B. 2017. SUMO E3 ligases GmSIZ1a and GmSIZ1b regulate vegetative growth in soybean. J. Integr. Plant Biol. 59:2-14.

Castaño-Miquel, L., Mas, A., Teixeira, I., Seguí, J., Perearnau, A., Thampi, B. N., Schapire, A. L., Rodrigo, N., La Verde, G., Manrique, S., Coca, M., and Lois, L. M. 2017. SUMOylation inhibition mediated by disruption of SUMO E1-E2 interactions confers plant susceptibility to necrotrophic fungal pathogens. Mol. Plant 10:709-720.

Castro, P. H., Couto, D., Freitas, S., Verde, N., Macho, A. P., Huguet, S., Botella, M. A., Ruiz-Albert, J., Tavares, R. M., Bejarano, E. R., and Azevedo, H. 2016. SUMO proteases ULP1c and ULP1d are required for development and osmotic stress responses in Arabidopsis thaliana. Plant Mol. Biol. 92:143-159.

Cesari, S., Bernoux, M., Moncuquet, P., Kroj, T., and Dodds, P. N. 2014. A novel conserved mechanism for plant NLR protein pairs: The "integrated decoy" hypothesis. Front. Plant Sci. 5:606

Cesari, S., Thilliez, G., Ribot, C., Chalvon, V., Michel, C., Jauneau, A., Rivas, S., Alaux, L., Kanzaki, H., Okuyama, Y., Morel, J. B., Fournier, E., Tharreau, D., Terauchi, R., and Kroj, T. 2013. The rice resistance protein pair RGA4/RGA5 recognizes the Magnaporthe oryzae effectors AVR-Pia and AVR1-CO39 by direct binding. Plant Cell 25:1463-1481.

Chakraborty, N., Curley, J., Frederick, R. D., Hyten, D. L., Nelson, R. L., Hartman, G. L., and Diers, B. W. 2009. Mapping and confirmation of a new allele from soybean PI 594538A conferring RB lesion-type resistance to soybean rust. Crop Sci. 49:783-790.

Chen, X., Liu, J., Lin, G., Wang, A., Wang, Z., and Lu, G. 2013 Overexpression of AtWRKY28 and AtWRKY75 in Arabidopsis enhances resistance to oxalic acid and Sclerotinia sclerotiorum. Plant Cell Rep. 32: 1589-1599.

Childs, S. P., King, Z. R., Walker, D. R., Harris, D. K., Pedley, K. F., Buck, J. W., Boerma, H. R., and Li, Z. 2018. Discovery of a seventh Rpp soybean rust resistance locus in soybean accession PI 605823. Theor. Appl. Genet. 131:27-41.

Conti, L., Price, G., O’Donnell, E., Schwessinger, B., Dominy, P., and Sadanandom, A. 2008. Small ubiquitin-like modifier proteases OVERLY TOLERANT TO SALT1 and -2 regulate salt stress responses in Arabidopsis. Plant Cell 20:2894-2908.

Cooper, B., Campbell, K. B., McMahon, M. B., and Luster, D. G. 2013. Disruption of Rppl-mediated soybean rust immunity by virus-induced gene silencing. Plant Signal. Behav. 8:e27543.

Dangl, J. L., and Jones, J. D. 2001. Plant pathogens and integrated defence responses to infection. Nature 411:826-833.

Dash, S., Campbell, J. D., Cannon, E. K. S., Cleary, A. M., Huang, W., Kalberer, S. R., Karingula, V., Rice, A. G., Singh, J., Umale, P. E.,
Weeks, N. T., Wilkey, A. P., Farmer, A. D., and Cannon, S. B. 2016. Legume information system (LegumeInfo.org): A key component of a set of federated data resources for the legume family. Nucleic Acids Res. 44:D1181-D1188.

de Carvalho, M. C., Costa Nascimento, L., Darben, L. M., PolizelPodanosqui, A. M., Lopes-Caitar, V. S., Qi, M., Rocha, C. S., Carazzolle, M. F., Kuwahara, M. K., Pereira, G. A., Abdelnoor, R. V., Whitham, S. A., and Marcelino-Guimarães, F. C. 2017. Prediction of the in planta Phakopsora pachyrhizi secretome and potential effector families. Mol. Plant Pathol. 18:363-377.

Dodds, P. N., and Rathjen, J. P. 2010. Plant immunity: Towards an integrated view of plant-pathogen interactions. Nat. Rev. Genet. 11: 539-548.

Du, J., Grant, D., Tian, Z., Nelson, R. T., Zhu, L., Shoemaker, R. C., and Ma, J. 2010. SoyTEdb: A comprehensive database of transposable elements in the soybean genome. BMC Genomics 11:113.

Elmore, J. M., Lin, Z. J., and Coaker, G. 2011. Plant NB-LRR signaling: Upstreams and downstreams. Curr. Opin. Plant Biol. 14:365-371.

Flor, H. H. 1946. Genetics of pathgenicity in Melampsora lini. J. Agric. Res. 73:337-357.

Garcia, A., Calvo, É. S., de Souza Kiihl, R. A., Harada, A., Hiromoto, D. M., and Vieira, L. G. E. 2008. Molecular mapping of soybean rust (Phakopsora pachyrhizi) resistance genes: Discovery of a novel locus and alleles. Theor. Appl. Genet. 117:545-553.

Gou, M., Huang, Q., Qian, W., Zhang, Z., Jia, Z., and Hua, J. 2017. Sumoylation E3 ligase SIZ1 modulates plant immunity partly through the immune receptor gene SNC1 in Arabidopsis. Mol. Plant-Microbe Interact 30:334-342.

Hane, J. K., Ming, Y., Kamphuis, L. G., Nelson, M. N., Garg, G., Atkins, C. A., Bayer, P. E., Bravo, A., Bringans, S., Cannon, S., Edwards, D. Foley, R., Gao, L. L., Harrison, M. J., Huang, W., Hurgobin, B., Li, S., Liu, C. W., McGrath, A., Morahan, G., Murray, J., Weller, J., Jian, J., and Singh, K. B. 2017. A comprehensive draft genome sequence for lupin (Lupinus angustifolius), an emerging health food: Insights into plantmicrobe interactions and legume evolution. Plant Biotechnol. J. 15: 318-330.

Hebsgaard, S. M., Korning, P. G., Tolstrup, N., Engelbrecht, J., Rouzé, P., and Brunak, S. 1996. Splice site prediction in Arabidopsis thaliana premRNA by combining local and global sequence information. Nucleic Acids Res. 24:3439-3452.

Hoen, D. R., Park, K. C., Elrouby, N., Yu, Z., Mohabir, N., Cowan, R. K., and Bureau, T. E. 2006. Transposon-mediated expansion and diversification of a family of $U L P$-like genes. Mol. Biol. Evol. 23: 1254-1268.

Hotson, A., Chosed, R., Shu, H., Orth, K., and Mudgett, M. B. 2003. Xanthomonas type III effector XopD targets SUMO-conjugated proteins in planta. Mol. Microbiol. 50:377-389.

Hyten, D. L., Hartman, G. L., Nelson, R. L., Frederick, R. D., Concibido, V. C., Narvel, J. M., and Cregan, P. B. 2007. Map location of the Rppl locus that confers resistance to soybean rust in soybean. Crop Sci. 47:837-838.

Hyten, D. L., Smith, J. R., Frederick, R. D., Tucker, M. L., Song, Q., and Cregan, P. B. 2009. Bulked segregant analysis using the GoldenGate assay to locate the locus that confers resistance to soybean rust in soybean. Crop Sci. 49:265-271.

Jones, J. D., Vance, R. E., and Dangl, J. L. 2016. Intracellular innate immune surveillance devices in plants and animals. Science 354:aaf6395.

Jones, J. D. G., and Dangl, J. L. 2006. The plant immune system. Nature 444:323-329.

Jones, P., Binns, D., Chang, H. Y., Fraser, M., Li, W., McAnulla, C., McWilliam, H., Maslen, J., Mitchell, A., Nuka, G., Pesseat, S., Quinn, A. F., Sangrador-Vegas, A., Scheremetjew, M., Yong, S. Y., Lopez, R., and Hunter, S. 2014. InterProScan 5: Genome-scale protein function classification. Bioinformatics 30:1236-1240.

Kawashima, C. G., Guimarães, G. A., Nogueira, S. R., MacLean, D., Cook, D. R., Steuernagel, B., Baek, J., Bouyioukos, C., Melo, B. V., Tristão, G., de Oliveira, J. C., Rauscher, G., Mittal, S., Panichelli, L., Bacot, K., Johnson, E., Iyer, G., Tabor, G., Wulff, B. B., Ward, E., Rairdan, G. J., Broglie, K. E., Wu, G., van Esse, H. P., Jones, J. D., and Brommonschenkel, S. H. 2016. A pigeonpea gene confers resistance to Asian soybean rust in soybean. Nat. Biotechnol. 34:661-665.

Kemen, E., Kemen, A. C., Rafiqi, M., Hempel, U., Mendgen, K., Hahn, M., and Voegele, R. T. 2005. Identification of a protein from rust fungi transferred from haustoria into infected plant cells. Mol. Plant-Microbe Interact 18:1130-1139.

Kendrick, M. D., Harris, D. K., Ha, B.-K., Hyten, D. L., Cregan, P. B., Frederick, R. D., Boerma, H. R., and Pedley, K. F. 2011. Identification of a second Asian soybean rust resistance gene in Hyuuga soybean. Phytopathology 101:535-543. 
Kojima, K. K., and Jurka, J. 2011. Crypton transposons: Identification of new diverse families and ancient domestication events. Mob. DNA 2:12.

Kong, X., Luo, X., Qu, G. P., Liu, P., and Jin, J. B. 2017. Arabidopsis SUMO protease ASP1 positively regulates flowering time partially through regulating FLC stability. J. Integr. Plant Biol. 59:15-29.

Kroj, T., Chanclud, E., Michel-Romiti, C., Grand, X., and Morel, J. B. 2016. Integration of decoy domains derived from protein targets of pathogen effectors into plant immune receptors is widespread. New Phytol. 210: 618-626.

Kunjeti, S. G., Iyer, G., Johnson, E., Li, E., Broglie, K. E., Rauscher, G., and Rairdan, G. J. 2016. Identification of Phakopsora pachyrhizi candidate effectors with virulence activity in a distantly related pathosystem. Front. Plant Sci. 7:269.

Larkin, M. A., Blackshields, G., Brown, N. P., Chenna, R., McGettigan, P. A., McWilliam, H., Valentin, F., Wallace, I. M., Wilm, A., Lopez, R., Thompson, J. D., Gibson, T. J., and Higgins, D. G. 2007. Clustal W and Clustal X version 2. Bioinformatics 23:2947-2948.

Lawrence, M., Gentleman, R., and Carey, V. 2009. rtracklayer: An R package for interfacing with genome browsers. Bioinformatics 25: 1841-1842.

Lawrence, M., Huber, W., Pagès, H., Aboyoun, P., Carlson, M., Gentleman, R., Morgan, M. T., and Carey, V. J. 2013. Software for computing and annotating genomic ranges. PLOS Comput. Biol. 9:e1003118.

Lee, J., Nam, J., Park, H. C., Na, G., Miura, K., Jin, J. B., Yoo, C. Y., Baek, D., Kim, D. H., Jeong, J. C., Kim, D., Lee, S. Y., Salt, D. E., Mengiste, T., Gong, Q., Ma, S., Bohnert, H. J., Kwak, S. S., Bressan, R. A., Hasegawa, P. M., and Yun, D. J. 2007. Salicylic acid-mediated innate immunity in Arabidopsis is regulated by SIZ1 SUMO E3 ligase. Plant J. 49:79-90.

Li, H., Handsaker, B., Wysoker, A., Fennell, T., Ruan, J., Homer, N., Marth, G., Abecasis, G., Durbin, R., and 1000 Genome Project Data Processing Subgroup. 2009. The Sequence Alignment/Map format and SAMtools. Bioinformatics 25:2078-2079.

Li, S., Smith, J. R., Ray, J. D., and Frederick, R. D. 2012. Identification of a new soybean rust resistance gene in PI 567102B. Theor. Appl. Genet. 125:133-142.

Li, S. J., and Hochstrasser, M. 1999. A new protease required for cell-cycle progression in yeast. Nature 398:246-251.

Li, S. J., and Hochstrasser, M. 2000. The yeast ULP2 (SMT4) gene encodes a novel protease specific for the ubiquitin-like Smt3 protein. Mol. Cell. Biol. 20:2367-2377.

Li, Y., Wang, G., Xu, Z., Li, J., Sun, M., Guo, J., and Ji, W. 2017. Organization and regulation of soybean SUMOylation system under abiotic stress conditions. Front. Plant Sci. 8:1458.

Link, T. I., Lang, P., Scheffler, B. E., Duke, M. V., Graham, M. A., Cooper, B., Tucker, M. L., van de Mortel, M., Voegele, R. T., Mendgen, K., Baum, T. J., and Whitham, S. A. 2014. The haustorial transcriptomes of Uromyces appendiculatus and Phakopsora pachyrhizi and their candidate effector families. Mol. Plant Pathol. 15:379-393.

Liu, L., Jiang, Y., Zhang, X., Wang, X., Wang, Y., Han, Y., Coupland, G., Jin, J. B., Searle, I., Fu, Y. F., and Chen, F. 2017b. Two SUMO proteases SUMO PROTEASE RELATED TO FERTILITY 1 and -2 are required for fertility. Plant Physiol. 175:1703-1719.

Liu, L., Yan, X., Kong, X., Zhao, Y., Gong, Z., Jin, J. B., and Guo, Y. 2017a. Transcriptional gene silencing maintained by OTS1 SUMO Protease requires a DNA-dependent polymerase V-dependent pathway. Plant Physiol. 173:655-667.

Malik, S., and Van der Hoorn, R. A. 2016. Inspirational decoys: A new hunt for effector targets. New Phytol. 210:371-373.

Maqbool, A., Saitoh, H., Franceschetti, M., Stevenson, C. E., Uemura, A., Kanzaki, H., Kamoun, S., Terauchi, R., and Banfield, M. J. 2015. Structural basis of pathogen recognition by an integrated HMA domain in a plant NLR immune receptor. eLife 4:e08709.

Martin, G. B., Bogdanove, A. J., and Sessa, G. 2003. Understanding the functions of plant disease resistance proteins. Annu. Rev. Plant Biol. 54: 23-61.

McLean, R. J., and Byth, D. E. 1980. Inheritance of resistance to rust (Phakopsora pachyrhizi) in soybeans. Aust. J. Agric. Res. 31:951-956.

Melching, J. S., Bromfield, K. R., and Kingsolver, C. H. 1983. The plant pathogen containment facility at Frederick, Maryland. Plant Dis. 67: 717-722.

Meyer, J. D. F., Silva, D. C. G., Yang, C., Pedley, K. F., Zhang, C., van de Mortel, M., Hill, J. H., Shoemaker, R. C., Abdelnoor, R. V., Whitham, S. A., and Graham, M. A. 2009. Identification and analyses of candidate genes for rpp4-mediated resistance to Asian soybean rust in soybean. Plant Physiol. 150:295-307.

Miles, M., Bonde, M., Nester, S., Berner, D., Frederick, R., and Hartman, G. 2011. Characterizing resistance to Phakopsora pachyrhizi in soybean. Plant Dis. 95:577-581.
Miles, M. R., Frederick, R. D., and Hartman, G. L. 2003. Is the U.S. soybean crop at risk? APSnet features. Published online. doi: .

Morales, A. M. A. P., O’Rourke, J., van de Mortel, M., Schneider, K. T., Bancroft, T. J., Borém, A., Nelson, R. T., Nettleton, D., Baum, T. J., Shoemaker, R. C., Frederick, R. D., Abdelnoor, R. V., Pedley, K. F., Whitham, S. A., and Graham, M. A. 2013. Transcriptome analyses and virus induced gene silencing identify genes in the Rpp4-mediated Asian soybean rust resistance pathway. Funct. Plant Biol. 40:1029-1047.

Morgan, M., and Pages, H. 2013. Rsamtools: Binary alignment (BAM), variant call $(\mathrm{BCF})$, or tabix file import ( $\mathrm{R}$ package version 1.12.4). Bioconductor. Published online. https://rdrr.io/bioc/Rsamtools

Mukhtar, M. S., Carvunis, A. R., Dreze, M., Epple, P., Steinbrenner, J., Moore, J., Tasan, M., Galli, M., Hao, T., Nishimura, M. T., Pevzner, S. J., Donovan, S. E., Ghamsari, L., Santhanam, B., Romero, V., Poulin, M. M., Gebreab, F., Gutierrez, B. J., Tam, S., Monachello, D., Boxem, M., Harbort, C. J., McDonald, N., Gai, L., Chen, H., He, Y., European Union Effectoromics Consortium, Vandenhaute, J., Roth, F. P., Hill, D. E., Ecker, J. R., Vidal, M., Beynon, J., Braun, P., and Dangl, J. L. 2011. Independently evolved virulence effectors converge onto hubs in a plant immune system network. Science 333:596-601.

Mumberg, D., Müller, R., and Funk, M. 1994. Regulatable promoters of Saccharomyces cerevisiae: Comparison of transcriptional activity and their use for heterologous expression. Nucleic Acids Res. 22:5767-5768.

Novatchkova, M., Tomanov, K., Hofmann, K., Stuible, H.-P., and Bachmair, A. 2012. Update on sumoylation: Defining core components of the plant SUMO conjugation system by phylogenetic comparison. New Phytol. 195:23-31.

Pandey, A. K., Yang, C., Zhang, C., Graham, M. A., Horstman, H. D., Lee, Y., Zabotina, O. A., Hill, J. H., Pedley, K. F., and Whitham, S. A. 2011 Functional analysis of the Asian soybean rust resistance pathway mediated by Rpp2. Mol. Plant-Microbe Interact 24:194-206.

Phukan, U. J., Jeena, G. S., and Shukla, R. K. 2016. WRKY transcription factors: Molecular regulation and stress responses in plants. Front. Plant Sci. 7:760.

Pretsch, K., Kemen, A., Kemen, E., Geiger, M., Mendgen, K., and Voegele, R. 2013. The rust transferred proteins-a new family of effector proteins exhibiting protease inhibitor function. Mol. Plant Pathol. 14:96-107.

Qi, M., Grayczyk, J. P., Seitz, J. M., Lee, Y., Link, T. I., Choi, D., Pedley, K. F., Voegele, R. T., Baum, T. J., and Whitham, S. A. 2018. Suppression or activation of immune responses by predicted secreted proteins of the soybean rust pathogen Phakopsora pachyrhizi. Mol. Plant-Microbe Interact 31:163-174.

Qi, M., Link, T. I., Müller, M., Hirschburger, D., Pudake, R. N., Pedley, K. F., Braun, E., Voegele, R. T., Baum, T. J., and Whitham, S. A. 2016. A small cysteine-rich protein from the Asian soybean rust fungus, Phakopsora pachyrhizi, suppresses plant immunity. PLoS Pathog. 12: e1005827.

R Core Team. 2014. R: A language and environment for statistical computing. R Foundation for Statistical Computing, Vienna, Austria.

Ray, J. D., Morel, W., Smith, J. R., Frederick, R. D., and Miles, M. R. 2009. Genetics and mapping of adult plant rust resistance in soybean PI 587886 and PI 587880A. Theor. Appl. Genet. 119:271-280.

Reeves, P. H., Murtas, G., Dash, S., and Coupland, G. 2002. early in short days 4, a mutation in Arabidopsis that causes early flowering and reduces the mRNA abundance of the floral repressor FLC. Development 129: 5349-5361.

Robinson, M. D., McCarthy, D. J., and Smyth, G. K. 2010. edgeR: A Bioconductor package for differential expression analysis of digital gene expression data. Bioinformatics 26:139-140.

Sadanandom, A., Ádám, É., Orosa, B., Viczián, A., Klose, C., Zhang, C., Josse, E.-M., Kozma-Bognár, L., and Nagy, F. 2015. SUMOylation of phytochrome-B negatively regulates light-induced signaling in Arabidopsis thaliana. Proc. Natl. Acad. Sci. U.S.A. 112:11108-11113.

Sahoo, D. K., Abeysekara, N. S., Cianzio, S. R., Robertson, A. E., and Bhattacharyya, M. K. 2017. A novel Phytophthora sojae resistance Rps12 gene mapped to a genomic region that contains several Rps genes. PLoS One 12:e0169950.

Saleh, A., Withers, J., Mohan, R., Marqués, J., Gu, Y., Yan, S., Zavaliev, R., Nomoto, M., Tada, Y., and Dong, X. 2015. Posttranslational modifications of the master transcriptional regulator NPR1 enable dynamic but tight control of plant immune responses. Cell Host Microbe 18:169-182.

Sarris, P. F., Cevik, V., Dagdas, G., Jones, J. D., and Krasileva, K. V. 2016. Comparative analysis of plant immune receptor architectures uncovers host proteins likely targeted by pathogens. BMC Biol. 14:8.

Sato, S., Nakamura, Y., Kaneko, T., Asamizu, E., Kato, T., Nakao, M., Sasamoto, S., Watanabe, A., Ono, A., Kawashima, K., Fujishiro, T., Katoh, M., Kohara, M., Kishida, Y., Minami, C., Nakayama, S., Nakazaki, N., Shimizu, Y., Shinpo, S., Takahashi, C., Wada, T., Yamada, 
M., Ohmido, N., Hayashi, M., Fukui, K., Baba, T., Nakamichi, T., Mori, H., and Tabata, S. 2008. Genome structure of the legume, Lotus japonicus. DNA Res. 15:227-239.

Schmutz, J., Cannon, S. B., Schlueter, J., Ma, J., Mitros, T., Nelson, W., Hyten, D. L., Song, Q., Thelen, J. J., Cheng, J., Xu, D., Hellsten, U., May, G. D., Yu, Y., Sakurai, T., Umezawa, T., Bhattacharyya, M. K., Sandhu, D., Valliyodan, B., Lindquist, E., Peto, M., Grant, D., Shu, S., Goodstein, D., Barry, K., Futrell-Griggs, M., Abernathy, B., Du, J., Tian, Z., Zhu, L., Gill, N., Joshi, T., Libault, M., Sethuraman, A., Zhang, X. C., Shinozaki, K., Nguyen, H. T., Wing, R. A., Cregan, P., Specht, J., Grimwood, J., Rokhsar, D., Stacey, G., Shoemaker, R. C., and Jackson, S. A. 2010. Genome sequence of the palaeopolyploid soybean. Nature 463:178-183.

Schmutz, J., McClean, P. E., Mamidi, S., Wu, G. A., Cannon, S. B., Grimwood, J., Jenkins, J., Shu, S., Song, Q., Chavarro, C., Torres-Torres, M., Geffroy, V., Moghaddam, S. M., Gao, D., Abernathy, B., Barry, K., Blair, M., Brick, M. A., Chovatia, M., Gepts, P., Goodstein, D. M., Gonzales, M., Hellsten, U., Hyten, D. L., Jia, G., Kelly, J. D., Kudrna, D., Lee, R., Richard, M. M. S., Miklas, P. N., Osorno, J. M., Rodrigues, J., Thareau, V., Urrea, C. A., Wang, M., Yu, Y., Zhang, M., Wing, R. A., Cregan, P. B., Rokhsar, D. S., and Jackson, S. A. 2014. A reference genome for common bean and genome-wide analysis of dual domestications. Nat. Genet. 46:707-713.

Schneider, K. T., van de Mortel, M., Bancroft, T. J., Braun, E., Nettleton, D., Nelson, R. T., Frederick, R. D., Baum, T. J., Graham, M. A., and Whitham, S. A. 2011. Biphasic gene expression changes elicited by Phakopsora pachyrhizi in soybean correlate with fungal penetration and haustoria formation. Plant Physiol. 157:355-371.

Shao, Z. Q., Xue, J. Y., Wu, P., Zhang, Y. M., Wu, Y., Hang, Y. Y., Wang, B., and Chen, J. Q. 2016. Large-scale analyses of angiosperm nucleotidebinding site-leucine-rich repeat genes reveal three anciently diverged classes with distinct evolutionary patterns. Plant Physiol. 170: 2095-2109.

Silva, D. C., Yamanaka, N., Brogin, R. L., Arias, C. A., Nepomuceno, A. L., Di Mauro, A. O., Pereira, S. S., Nogueira, L. M., Passianotto, A. L., and Abdelnoor, R. V. 2008. Molecular mapping of two loci that confer resistance to Asian rust in soybean. Theor. Appl. Genet. 117:57-63.

Solovyev, V., Kosarev, P., Seledsov, I., and Vorobyev, D. 2006. Automatic annotation of eukaryotic genes, pseudogenes and promoters. Genome Biol. 7:S10.

Tang, H., Krishnakumar, V., Bidwell, S., Rosen, B., Chan, A., Zhou, S., Gentzbittel, L., Childs, K. L., Yandell, M., Gundlach, H., Mayer, K. F., Schwartz, D. C., and Town, C. D. 2014. An improved genome release (version Mt4.0) for the model legume Medicago truncatula. BMC Genomics 15:312.

Tian, M., Win, J., Song, J., van der Hoorn, R., van der Knaap, E., and Kamoun, S. 2007. A Phytophthora infestans cystatin-like protein targets a novel tomato papain-like apoplastic protease. Plant Physiol. 143:364-377.

Trapnell, C., Pachter, L., and Salzberg, S. L. 2009. TopHat: Discovering splice junctions with RNA-seq. Bioinformatics 25:1105-1111.

Treco, D.A., and Winston, F. 2008. Growth and manipulation of yeast. Curr. Protoc. Mol. Biol. 82:13.12.11-13.12.12.

van de Mortel, M., Recknor, J. C., Graham, M. A., Nettleton, D., Dittman, J. D., Nelson, R. T., Godoy, C. V., Abdelnoor, R. V., Almeida, A. M. R., Baum, T. J., and Whitham, S. A. 2007. Distinct biphasic mRNA changes in response to Asian soybean rust infection. Mol. Plant-Microbe Interact 20:887-899.

van den Burg, H. A., and Takken, F. L. 2010. SUMO-, MAPK-, and resistance protein-signaling converge at transcription complexes that regulate plant innate immunity. Plant Signal. Behav. 5:1597-1601.

van der Hoorn, R. A., and Kamoun, S. 2008. From guard to decoy: A new model for perception of plant pathogen effectors. Plant Cell 20: 2009-2017.

van Esse, H. P., Van't Klooster, J. W., Bolton, M. D., Yadeta, K. A., van Baarlen, P., Boeren, S., Vervoort, J., de Wit, P. J., and Thomma, B. P. 2008. The Cladosporium fulvum virulence protein Avr2 inhibits host proteases required for basal defense. Plant Cell 20:1948-1963. van Leeuwen, H., Monfort, A., and Puigdomenech, P. 2007. Mutator-like elements identified in melon, Arabidopsis and rice contain ULP1 protease domains. Mol. Genet. Genomics 277:357-364.

Varshney, R. K., Chen, W., Li, Y., Bharti, A. K., Saxena, R. K., Schlueter, J. A., Donoghue, M. T. A., Azam, S., Fan, G., Whaley, A. M., Farmer, A. D., Sheridan, J., Iwata, A., Tuteja, R., Penmetsa, R. V., Wu, W., Upadhyaya, H. D., Yang, S. P., Shah, T., Saxena, K. B., Michael, T., McCombie, W. R., Yang, B., Zhang, G., Yang, H., Wang, J., Spillane, C., Cook, D. R., May, G. D., Xu, X., and Jackson, S. A. 2012. Draft genome sequence of pigeonpea (Cajanus cajan), an orphan legume crop of resource-poor farmers. Nat. Biotechnol. 30:83-89.

Verma, V., Croley, F., and Sadanandom, A. 2018. Fifty shades of SUMO: Its role in immunity and at the fulcrum of the growth-defence balance. Mol. Plant Pathol. 19:1537-1544.

Wang, Q., Qu, G. P., Kong, X., Yan, Y., Li, J., and Jin, J. B. 2018. Arabidopsis small ubiquitin-related modifier protease ASP1 positively regulates abscisic acid signaling during early seedling development. J. Integr. Plant Biol. 60:924-937

Wang, Z., Libault, M., Joshi, T., Valliyodan, B., Nguyen, H. T., Xu, D., Stacey, G., and Cheng, J. 2010. SoyDB: A knowledge database of soybean transcription factors. BMC Plant Biol. 10:14.

Wessling, R., Epple, P., Altmann, S., He, Y., Yang, L., Henz, S. R., McDonald, N., Wiley, K., Bader, K. C., Glässer, C., Mukhtar, M. S., Haigis, S., Ghamsari, L., Stephens, A. E., Ecker, J. R., Vidal, M., Jones, J. D., Mayer, K. F., Ver Loren van Themaat, E., Weigel, D., SchulzeLefert, P., Dangl, J. L., Panstruga, R., and Braun, P. 2014. Convergent targeting of a common host protein-network by pathogen effectors from three kingdoms of life. Cell Host Microbe 16:364-375.

Whitham, S. A., Lincoln, L. M., Chowda-Reddy, R. V., Dittman, J. D., O'Rourke, J. A., and Graham, M. A. 2016. Virus induced gene silencing and transient gene expression in soybean (Glycine max) using Bean pod mottle virus infectious clones. Curr. Protoc. Plant Biol. 1:263-283.

Wickham, H. 2009. ggplot2: Elegant graphics for data analysis. In: Use R! Springer-Verlag, New York.

Xie, C., Zhou, X., Deng, X., and Guo, Y. 2010. PKS5, a SNF1-related kinase, interacts with and phosphorylates NPR1, and modulates expression of WRKY38 and WRKY62. J. Genet. Genomics 37: 359-369.

Zhan, E., Zhou, H., Li, S., Liu, L., Tan, T., and Lin, H. 2018. OTS1dependent deSUMOylation increases tolerance to high copper levels in Arabidopsis. J. Integr. Plant Biol. 60:310-322.

Zhang, C., Bradshaw, J. D., Whitham, S. A., and Hill, J. H. 2010. The development of an efficient multipurpose bean pod mottle virus viral vector set for foreign gene expression and RNA silencing. Plant Physiol. 153:52-65.

Zhang, C., Yang, C., Whitham, S. A., and Hill, J. H. 2009. Development and use of an efficient DNA-based viral gene silencing vector for soybean. Mol. Plant-Microbe Interact 22:123-131.

\section{AUTHOR-RECOMMENDED INTERNET RESOURCES}

American Type Culture Collection database: www.atcc.org

The Arabidopsis Information Resource (TAIR): www.arabidopsis.org

European Saccharomyces cerevisiae Archive for Functional Analysis (Euroscarf): http://www.euroscarf.de/search

Legume Information System Genomic Context Viewer:

https://legumeinfo.org/lis_context_viewer

National Center for Biotechnology Sequence Read Archive: https://www.ncbi.nlm.nih.gov/sra

The SoyBase database: https://www.soybase.org/genomeannotation

The SoyBase Gene Model Correspondence Lookup:

https://www.soybase.org/correspondence

The SoyBase GO Term Enrichment tool:

https://www.soybase.org/goslimgraphic_v2/dashboard.php 